\title{
الطلاق العاطفي بين الزوجين وعلاقته بالإتزان الإنفعالي عند الأبناء
}

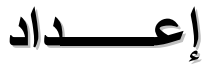 \\ د. نور الاين طه يوسف السنباري \\ دكتوراه الإرشاد النفسي - جامعة القاهرة
}

Doi: 10.12816/0044439

مجلة الاراسات التريوية والانسانية ـ كلية التربية ـ جامعة دمنهور

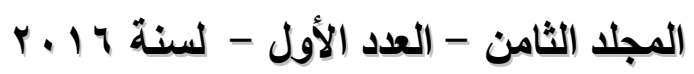

"ISSN 2090-7885"

(PRINT) 
الطلاق العاطفى بين الزوجين وعلاقته بالإتزان الإنفعالى عند الأبناء د. نور الدين طه السنبارى . 
الطلاق العاطفي بين الزوجين وعلاقته بالإتزان الإنفعالي عند الأبناء

د. نور الاين طه السنباري

\section{Doi: 10.12816/0044439}

مقدمـة الدراسـة:

الأسرة عماد المجتمع البشري، وأساس الاستقرار النفسي للإنسان المسلم قال تعالى

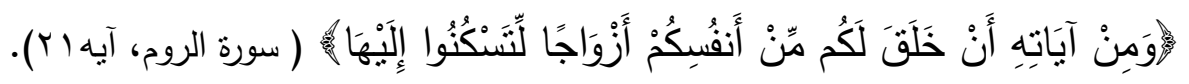

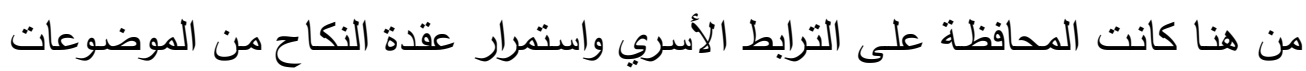

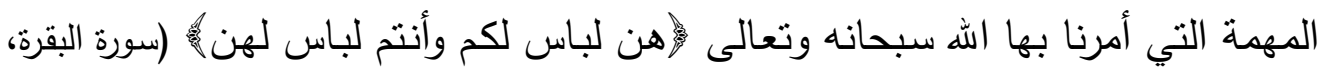

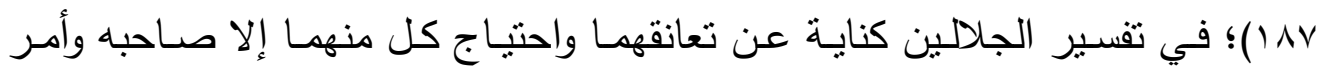

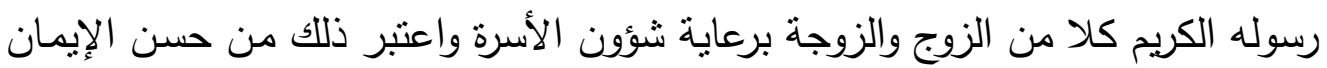

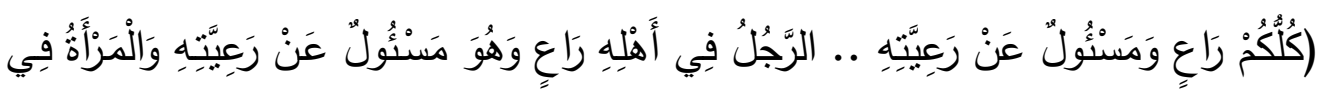

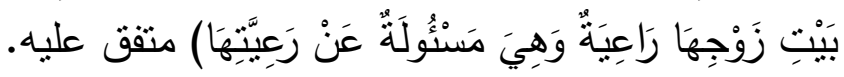
وتمثل الأسرة اللبنة الأولى لتتكيل شخصية الابناء وتلقينهم المبادئ الأولية في التشئئة

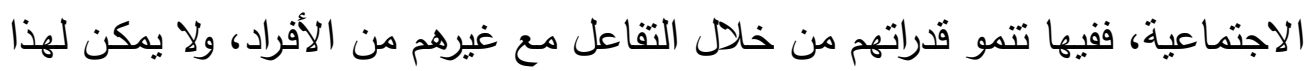

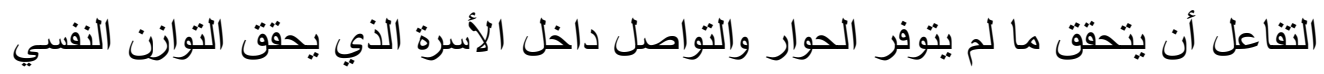

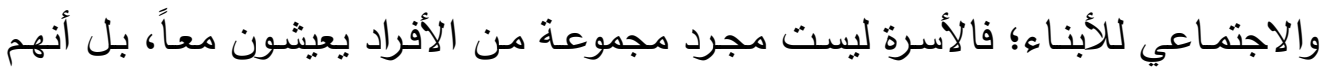
يدخلون في تفاعلات وعلاقات مستمرة ووثثقة، فكلما كانت الاستجابة بين أفراد الأسرة

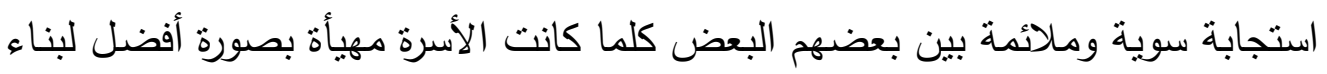
علاقات قوية، وتكون قادرة على مواجهة المشكلات التي ترتبط بسلوك الأبناء، حيث

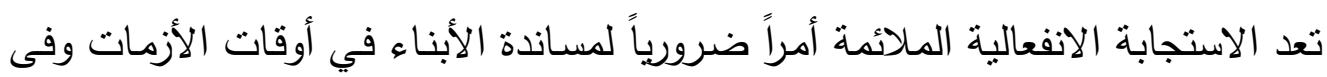

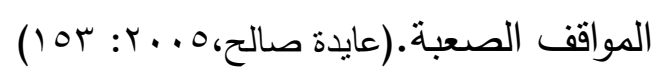
والطلاق العاطفي هو أحد الموضوعات المهمة التي ينبغي أن تحظى بقدر كبير من

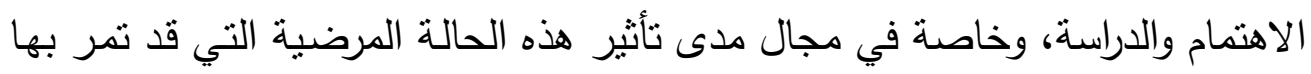

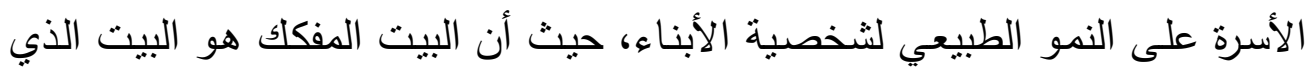


عُرف منذ زمن على أنه نقطة رئيسية في انعدام التكيف، حيث أثبت الدراسات المختلفة

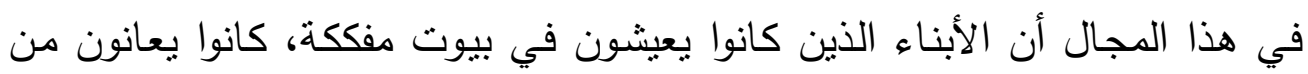

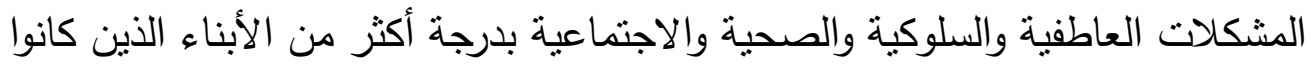

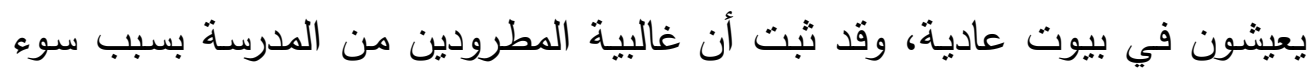

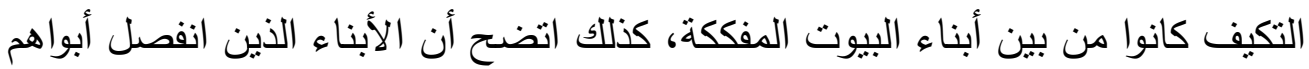

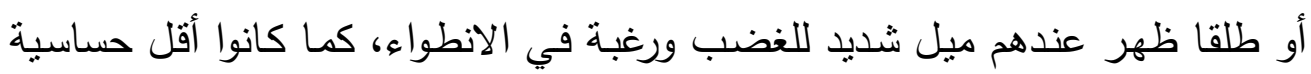

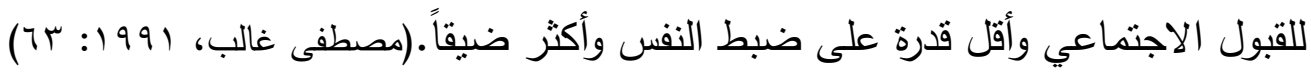

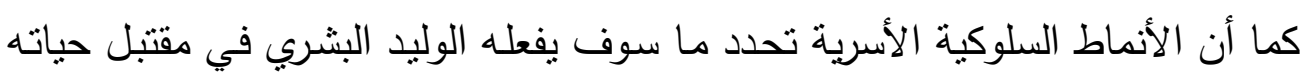

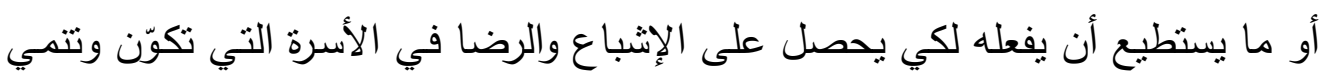

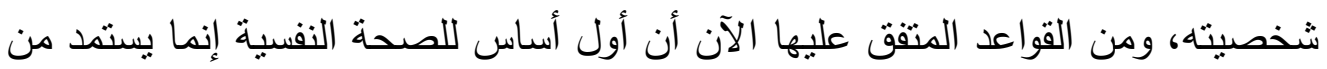

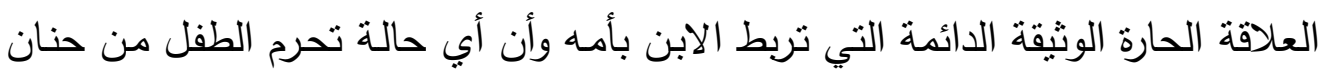

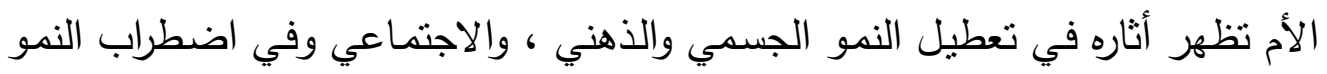

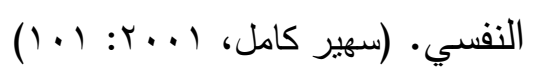

فإن الجو الأسرى والاتجاهات الوالدية لها أثرها على التكوين النفسي للابن، وعندما

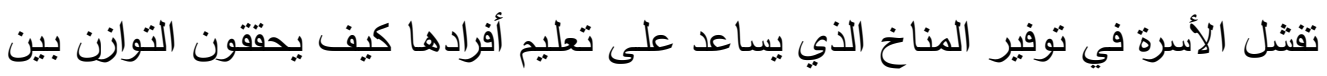

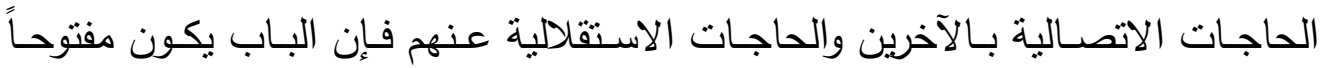
لمختلف صور الاتصال الخاطئ، والذي ينتهي باضطراب جو الأسرة وتحويلها لبؤرة مولّدة للاضطراب، بل وإصابة بعض أفرادها بالاضطراب الواضح الصريح. لعاء بلاء كفافي، (109:1999

كما قد يؤدي الاضطراب والطلاق العاطفي إلى عواقب وخيمة على نمو الابن وصحته

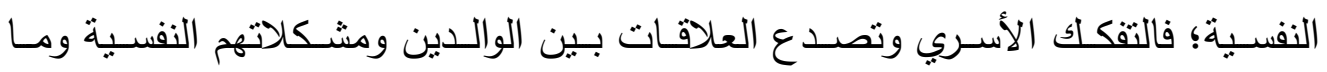
يصاحب ذللك كله من عدم احترام وتحقير كل طرف منهما للآخر ، واللامبالاة والعداوة

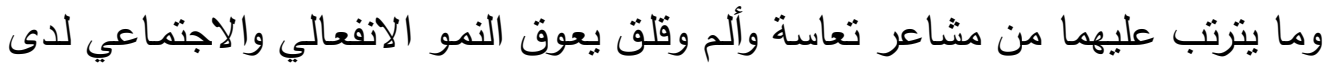

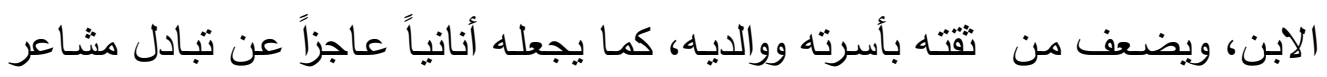
Doi: 10.12816/0044439 
الحب مع الآخرين ويفقده الانتماء، وربما دفعه إلى أنتكال مختلفة من الانحراف والسلوك

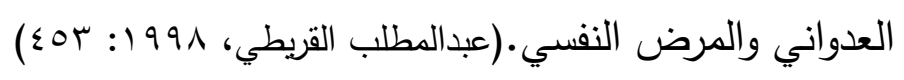

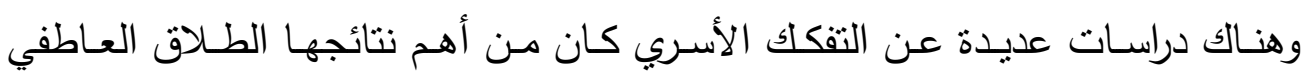

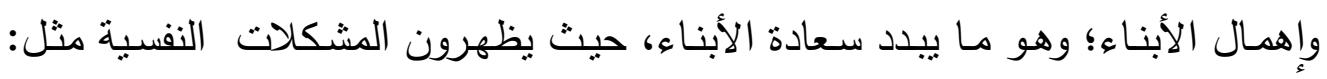
الكوابيس الثديدة المتكررة، والثكاوى النفسجمية مثل الصداعاع، وآلام المعدة، والتبول

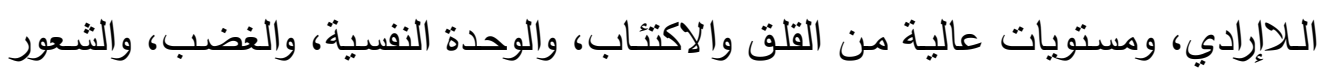

بالذنب. (Oates, 1996: 46) لذا فإن أهم الآثار السلبية للطلاق العاطفي بين الزوجين على النمو النفسي للابن هو

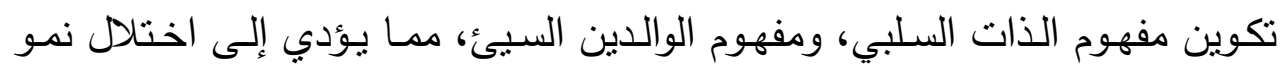

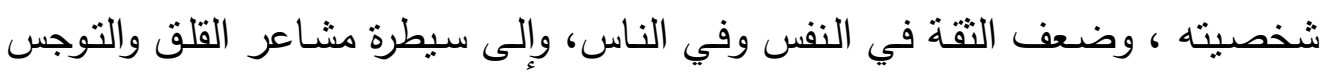

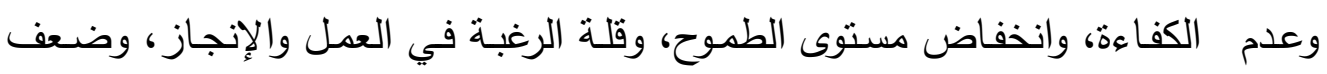
التحصيل الدراسي. (عبدالمطلب القريطي، وعهم 1991:

\section{مشكلة الاراسة:}

الأسرة من أهم المؤسسات الاجتماعية في بنـاء شخصية الأبناء من جميع النواحي

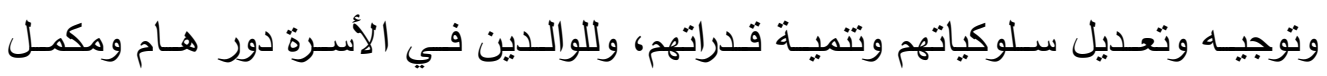
لبعضهما البعض حيث تمثل الأم الدور البيولوجي والنفسي، بينما يمثل الأب القانون

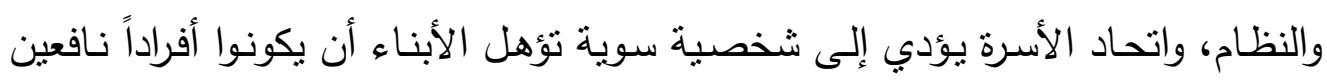
لأنفسهر ولمجتمعهم الذي يعيشون فيه.

والخلافات العائلية المستمرة بين الزوجين تؤدي إلى أن الحياة الزوجية تكون غير

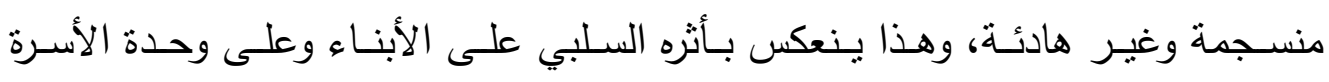

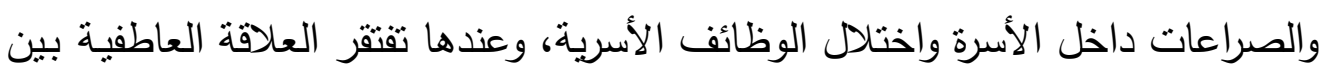

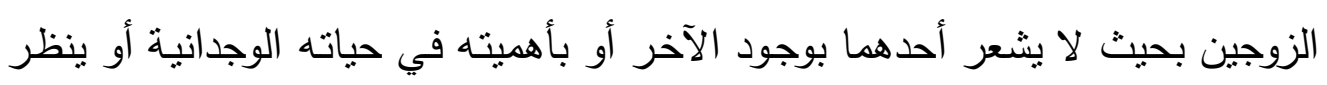
كل منهما للآخر على أنه غريب، حيث أن التفكل الأسرى هو انهيار الوحدة الأسرية 
وتُحَلِل أو تُمَزق نسيج الأدوار الاجتماعية، ويخفق فرد أو أكثر من أفرادها في القيام

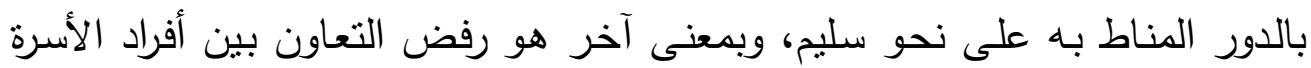

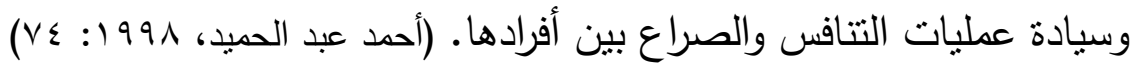
فالأسرة تلعب دوراً فعالاً في النمو السوي لنخصية الابن، وأن النمو النفسي لأي

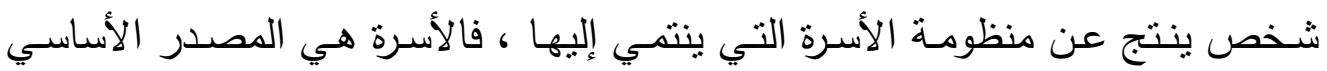

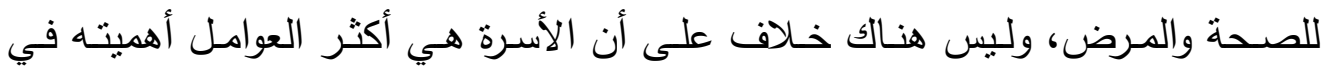

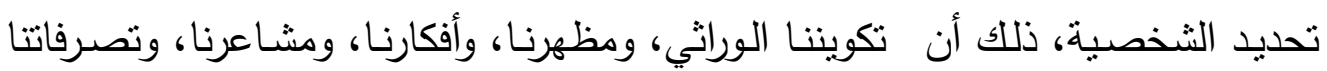

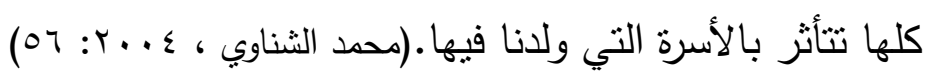
وقد يكون للتفكلك الأسري نوعان هما التفكلك أو التصدع، حيث يعتبر التصدع المادي

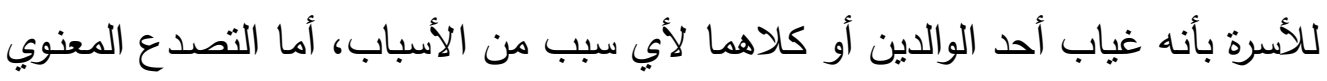

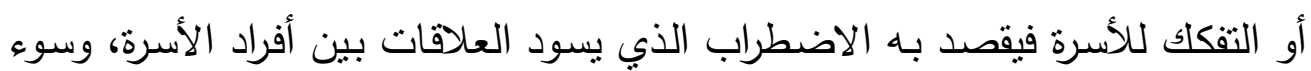

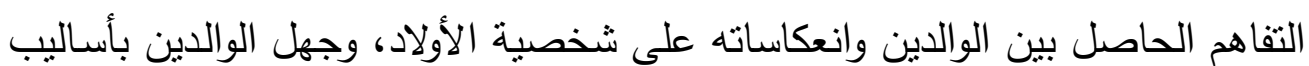
التربية السليمة. (علي جعفر، ـ991: זٓ) وسواء كان تفكلك الأسرة كلياً أو تفككاً معنوياً، يبقى لهذا النوع من الأسر نأثيراً بالغاً

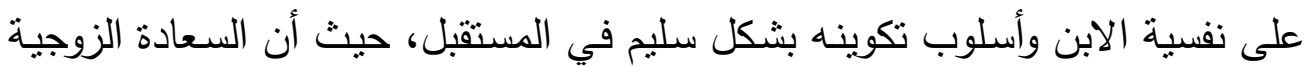

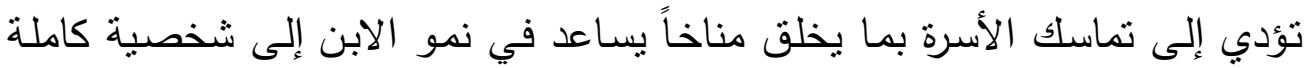

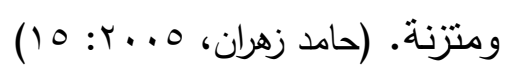

وعملية المشاجرة قد تتشأ نتيجة وجود شخصيات مفككة في الموقف الأسري لا نستطيع

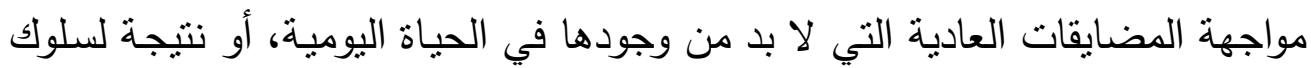
الزوجة التي لا تجد متعة في الحياة إلا في تذكير زوجها وأبنائهما بما تلاحظه من لناهن قصور في أداء واجباتهم، أو قد تكون من صنع شخص يميل إلى الفضفاضـة وإثاعة النكد في الجو الأسري، أو نتيجة رغبة أحد الأفراد في فرض مطالب منطرفة فئة على بقية

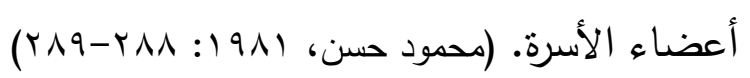


فالتفكك الأسري يلعب دوراً جوهرياً وحاسماً في ظهور الاضطرابات النفسية لدى الأبناء

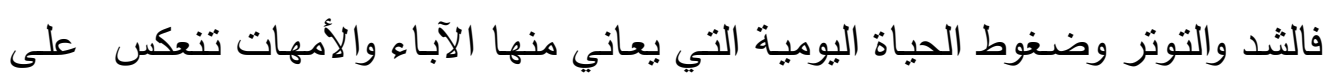

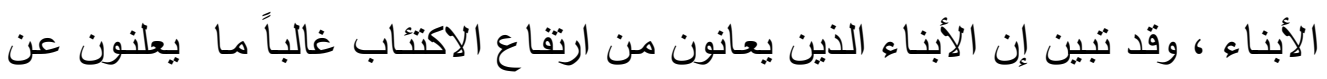

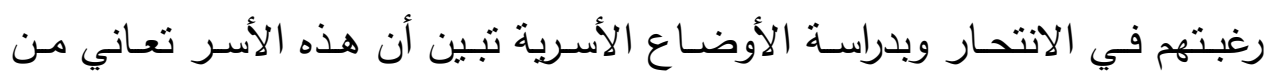

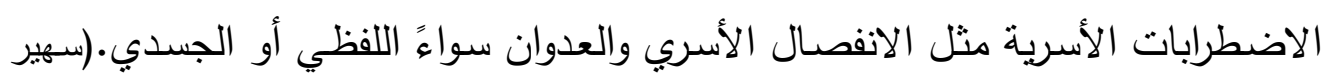

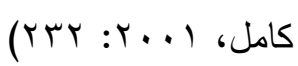
حيث تؤكد الدراسات والأبحاث في مجال العلوم التربوية والنفسية أن الابن يكون دائماً بحاجة إلى أن ينمو في كنف أسرة مستقرة من الوالدين، وأن تعرض الأسرة إلى التفكلك والتصدع له تأثثير كبير على شخصية الابن بصفه عامة وعلى نفسيته بصفه خاصـة،

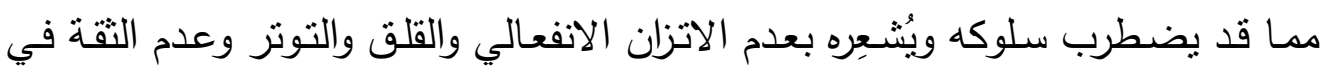
النفس، من هنا جاءت مشكلة الدر اسة والتي تتبلور في التساؤلات التالية:ـ هل هنالك علاقة بين الطلاق العاطفي عند الزوجين و الاتزان الانفعالي للأبناء؟ •-هل هنالك فروق في الاتز ان الانفعالي للأبناء بحسب النوع؟

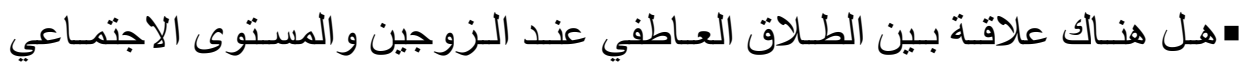

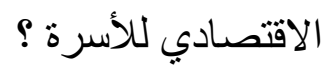

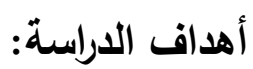
• الكثنف عن مدى إمكانيـة وجود علاقة بين الطـلاق العـاطفي عند الزوجين والاتزان الانفعالي لاى الأبناء. - الكثف عن مدى وجود فروق في الاتزان الانفعالي لاى الأبناء بحسب النوع.

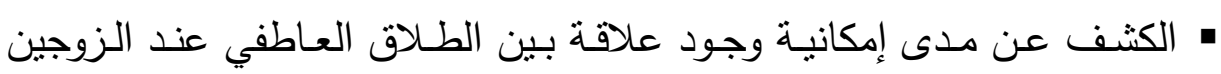
والمستوى الاجتماعي الاقتصادي للأسرة. 
• تأتي أهمية هذه الدراسة لأهمية الاستقرار الزوجي والأسري الذي يجب أن يتمتع بـ الزوجان؛ والذي ينعكس بآثاره على تحقيق الاتزان الانفعالي لدى الأبناء.

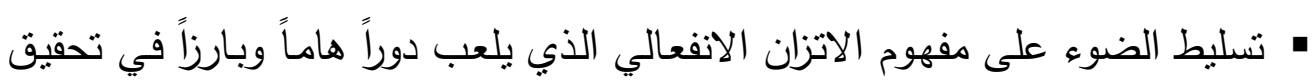
توافق الابن، وبالتالي سيطرته على ذاته. " ندرة الدراسات التي تتاولت الطلاق العاطفي بين الزوجين - على حد على على الباحثـوأثره على الصحة النفسية للأبناء. مصطلحات الدراسة الإجرائية: وتتمنل في: Iـ الطلاق العاطفي Emotional Divorce:

يتبنى الباحث تعريف (محمد النابلسي، .99 1: 40) وهو : الطلاق غير المعلن على الملأ بل انه يكون أحياناً من طرف واحد في حين يمكن للطرف الآخر أن يجهله كلياً،

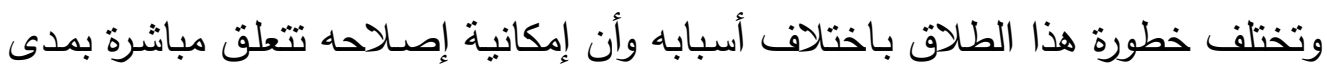
جدية الأسباب المؤدية إليه والذي يقتضي الوقوف عنده طويلاً، وبعض المصادر بادئ تطلق

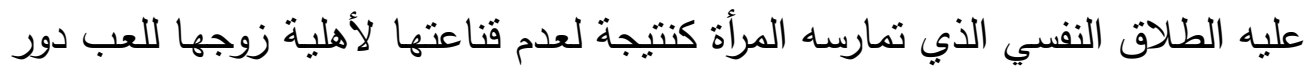

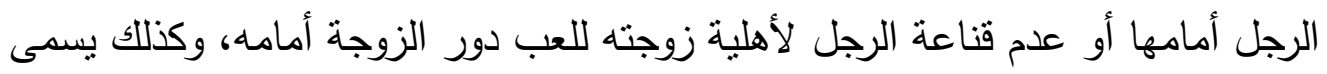

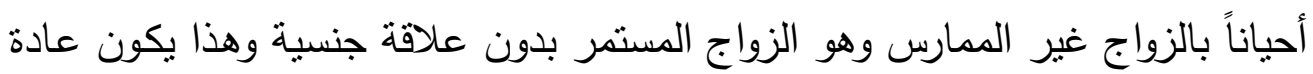
مقدمة للطلاق أو ربما الهجر الذي يسبق الطلاق النهائي. ويضيف الباحث بأنه: يقاس بمجموع الدرجات التي يحصل عليها الزوجين على مقياس الطلاق العاطفي المستخدم. r ـ الاتزان الانفعالي لدى الأبناء Emotional Stability: يتبنى الباحث تعريف (عادل العدل، 990 (1) 1) وهو : وسط فاصل على متصل ينتهي من ناحية عند الترددية ومن ناحية أخري عند الاندفاعية، وبهذا يكون الاتزان Doi: 10.12816/0044439 
الانفعالي تحكماً وسيطرة علي الذات تتيح لصاحبها أن يحتل مكانة في نقطة ما من وسط المتصل.

ويضيف الباحث بأنه: الدرجة التي يحصل عليها الابن على المقياس المستخدم

$$
\text { في الدراسة. }
$$

\section{الإطار النظري للاراسة والدراسات السابقة:}

\section{أـ الطلاق العاطفي Emotional Divorce:}

يُعرّف الطلاق العاطفي بأنه حالة من الاختلاف الداخلي والخارجي الناجم عن وجود

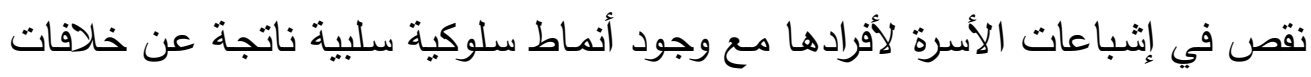

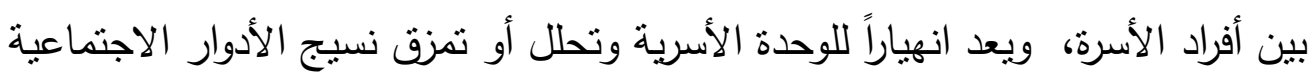

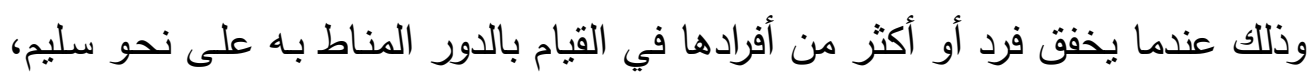

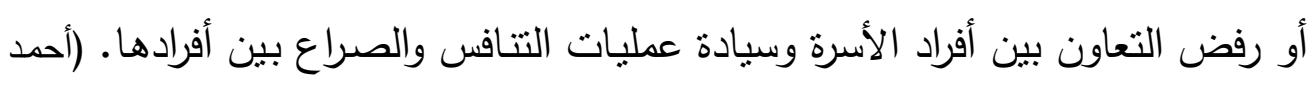

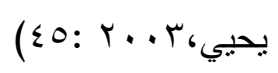

فالحياة الزوجية تقوم بين طرفين؛ كل منهما قد نشأ في ظروف قد تختلف تماماً عن الظروف التي نشأ فيه الطرف الآخر ، فكل منهما له شخصيته وأنماطه السلوكية، وقيمه لهنه

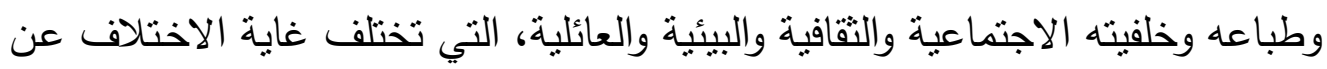
الآخر ؛ فكل من الزوجين قد يختلف في تكوينه الجسماني والعاطفي عن الطرف الآخر

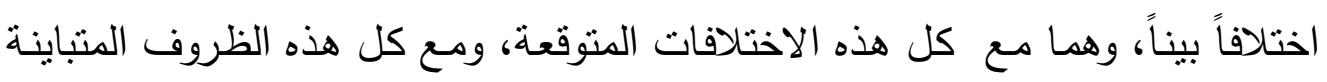
والخصائص الفردية المميزة، إذا ما تراضيا على الزواج، وأحس كل منهما برغبة منتبادلة

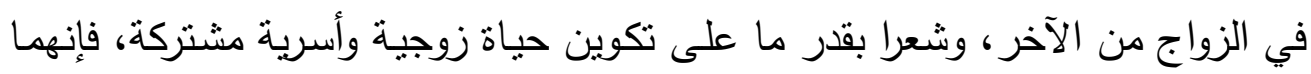
لابد أن يعملا على إقامة حياة ناجحة سعيدة، وذلك راجع لقبول كل منهمها مشـاركة

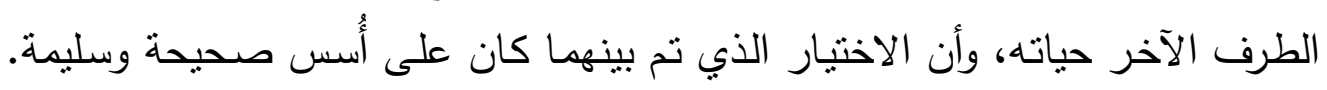

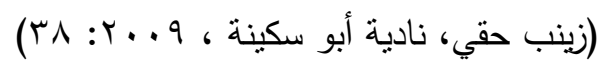


والطـلاق العـاطفي هـو الاخـتلاف النسبـي بـين الـزوجين على موضـوعات حيـاتهم

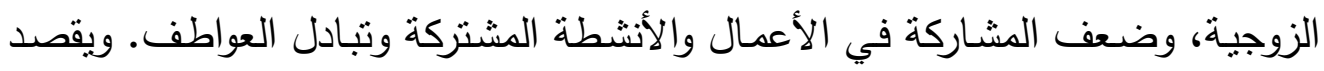
بالطلاق اتجاه التفاعل بين الوحدات التي تتكون منها الأسرة ضد المستويات الاجتماعية

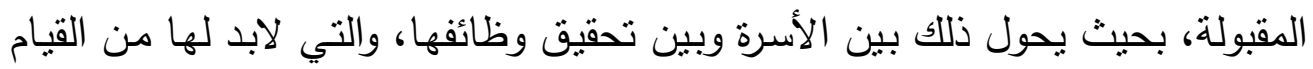
بها، لتوفير الاستقرار والتكامل بين أفرادها. وقد تتداخل الأسباب والعوامل المؤدية إلى ظاهرة الطلاق العاطفي، فمنها ما هو تابع إلى محددات نفسية متعلقة بعدم إثباع الحاجات النفسية وعدم التوافق ألزواجي والملل

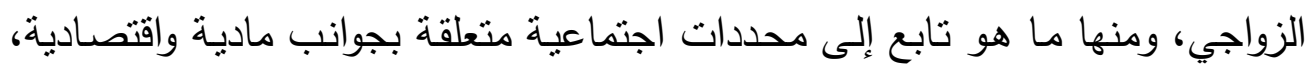
وكذا تدخل أهل الزوجة وأهل الزوج في حياتهما في محاولة للسيطرة عليها وتوجيههما،

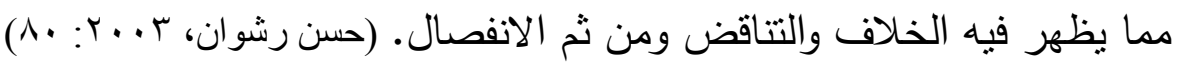
وقد حدد محمد غيث (1991) الأزمة الزواجية في عدة مظاهر كما يلي: اختفـاء الأهـداف المشـتركة بـين الـزوجين وكذللك الاهتمامـات المتبادلـة، وتصـبح النزعات والأهداف الفردية أكثر أهمية من الأهداف الأسرية.

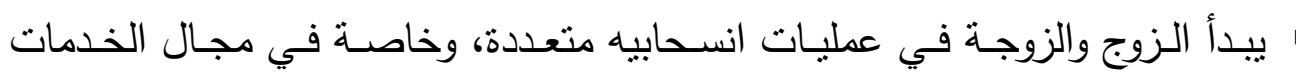
المتبادلة سواء داخل الوحدة الأسرية أو خارجها. يظهر التناقض في مجالات العلاقات الشخصية المتبادلة، أو بمعنى آخر لا يكون هناك اتساق في الرغبات و تزداد فرص الاصطدام. يتغير شكل وموضوع التفاعل بين الزوجين.

• تتعارض الاتجاهات العاطفية للزوجين فتتخذ العلاقات الزواجية طابعاً سطحياً. (في: وفاء خليل (1991: ومن خلا التركيز على المظاهر المعرفية لاضطراب العلاقة الزوجية يرى بيك (Beck,1989:9) تحول التصورات الايجابية الجيدة عن شريك الحياة إلى تصورات أخرى سيئة. 
نظرة كل شريك إلى الحدث نفسه بطريقة مختلفة تماماً.

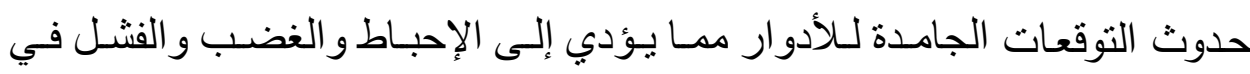

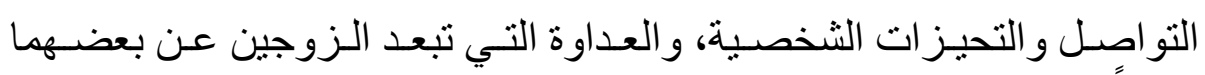
بعضاً.

ويتفق الكثير من الباحثين و المفكرين على أن للأسرة المفككة أو المتصدعة أشكالاً

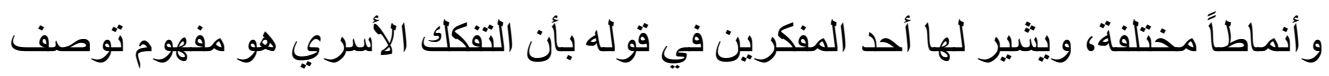

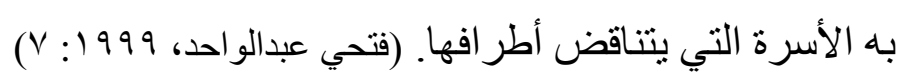

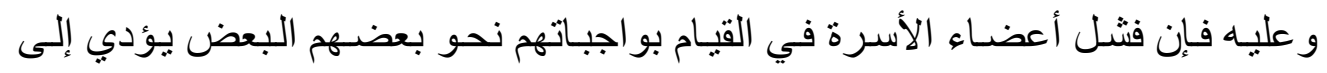
ضعف العلاقات وحدوث التوترات بين أفر ادها، وهذا يؤدى إلى انفر اط عقد الأسرة.

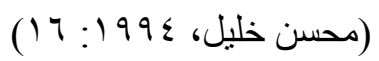
و هناك العديد من النظريات الاجتماعية التي ركزت على التفاعل و العلاقات المتبادلة بين الزوجين وتوقعات كل منهما عن العلاقة الزوجية ومن هذه النظريات:

\section{أولاً: النظرية الوظيفية:}

يـرى أنصـار هذه النظريـة أن لكل فرد في المجتهـع مجموعـة مـن الاحتياجـات الغريزية والاجتماعية والعاطفية التي يسعى إلى إثباعها ويحاول كل مجتمع إثباعها

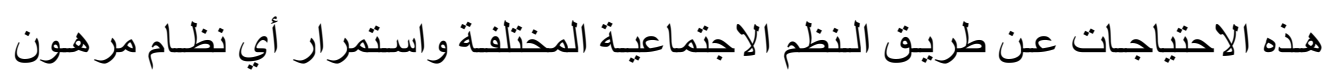
بالوظائف التي تؤدي لإشباع هذه الحاجات و إذا فقد هذا الجزء وظيفته انتهى بـالزو ال،

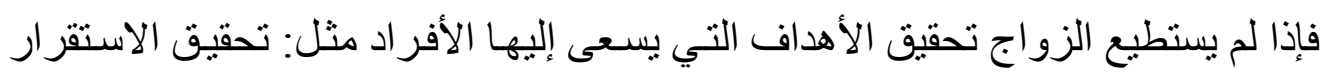

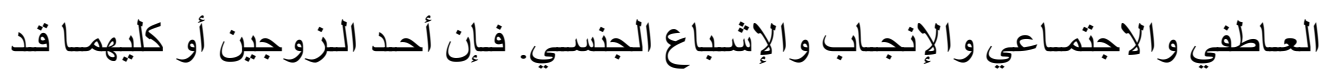

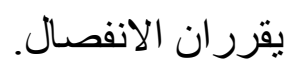

\section{ثانياً: النظرية التفاعلية الرمزية:}

كل أسـرة لها مجموعـة مـن الرموز و المعـيير التـي تعلمها لأبنائها في مرحلـة

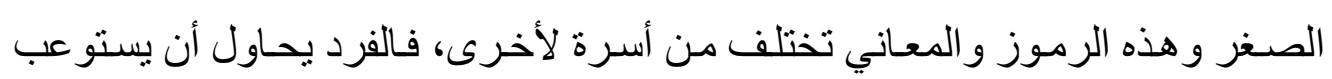
rq 
الدور المتوقع منـهـ أولاً ثم يحـاول من خـلال تعاملهـ اليومي مـع الأخرين إدخـال بعض

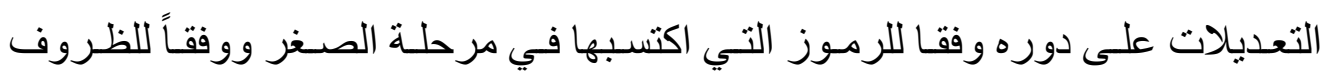

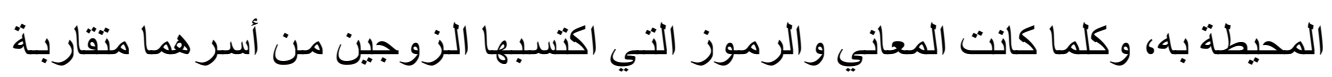

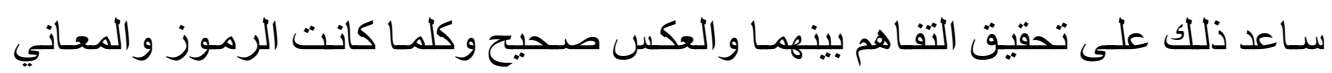
متباعدة ومتنافرة بين الزوجين أدى ذلك إلى خلق فجوة بينهما.

ثالثاً: النظرية التبادلية: - n

وترى هذه النظرية أن الأفر اد يدخلون مع بعضهم البعض في علاقات تبادلية فهم

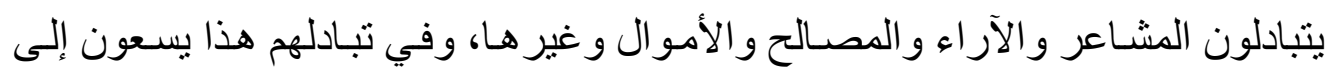

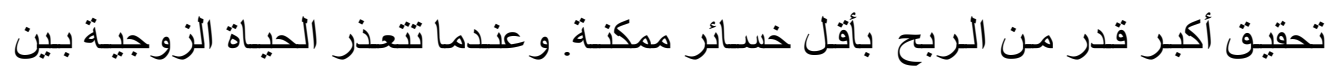

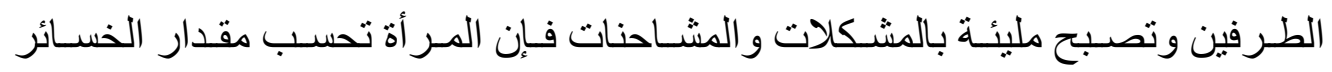

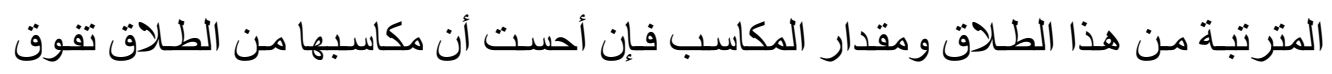
خسائر ها فأنها تتخذ قرار الطلاق، و إذا كانت الخسائر أكثر من المكاسب فإنها ستستمر النهر في حياتها الزوجية ، وأن هذه المكاسب أو الخسائر هنـا ليست ماديـة فقطو أنـا ماديـة

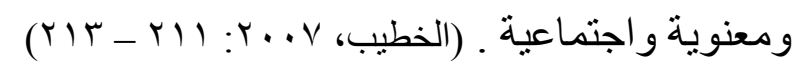

ومما سبق نجد أن اختيار أحد الزوجين أو كلاهما قد تصب في كثير من الأحيان تجاه الطلاق العاطفي، ولكن الطلاق العاطفي لا يحدث بين ليلة وضحاها، فلا يحدث

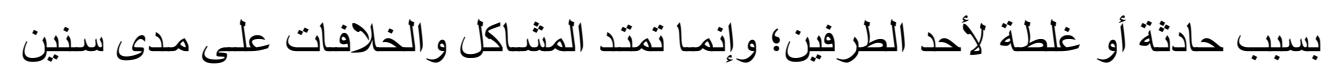

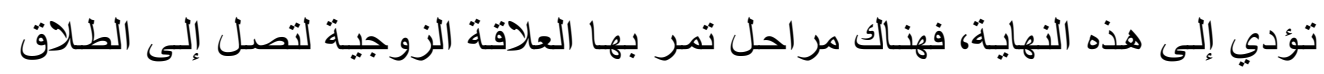

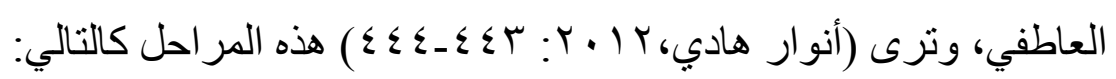
ا. زعزعة الثقة وفقدانها: فالتقة بين الزوجين هي مقدار المصداقية في القول و الفعل التي يتمتع بها كل طرف عند الطرف الآخر. 


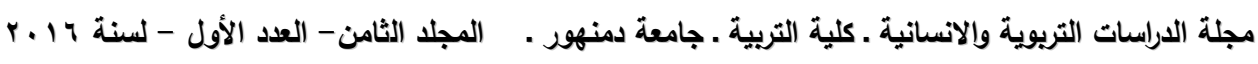

ץ. فتور الحب وفقدانه: وفيها يشعر الطرفان أو أحدهما إن عاطفته لم تعد كمـا كانت

في السابق ولم يعد منجذباً له بل صار منصرفاً عنه و لا يكاد يلتفت إليه و لا ينظر له نظر ات الحب و الإعجاب ويميل إلى تضخيم عيو به فيبدو ا عازفاً عن حبـه وتودده

ب. الأنانيـة: تسـاهم الأنانيـة في هدم قواعد الأسرة عندما يفكر كل منهمـا بنفسـه وبمصلحته فقط دون مراعاة لمصلحة الطرف الآخر وهذه عقبة في طريق

$$
\text { الإصلاح بين الزوجين. }
$$

وبناء على ماسبق فإن الباحث يرى بأن الطلاق العـاطفي هو المرحلـة الرماديـة التي تكون لاحقة على المرحلة البيضـاء وهي التفـاهم و التو اصل الزو اجي؛ وتسبق المرحلة السوداء وهي الطلاق الفعلي، وفي هذه المرحلة من الممكن التقاط الأنفاس لإعـادة النظر و التفكير في العلاقة الزوجية إن كانت سوف تظل جامدة ومستقرة عند هذا المستوى أم سـوف تعـود إلى المنطقـة البيضـاء وهـى التفـاهم الزو اجـي أم سـوف تتقدم إلى مرحلـة الطلاق الفعلي. و عليـه يـرى الباحث إن كـان الطـلاق العـاطفي هـو مرحلـة لإعـادة تقيـيم المواقف، ور اجعة التصـرفات، و التهـاس الأعذار للطرف الآخر ؛ فقطعاً هو حل جيد جداً على الأقل على مستوى الحفاظ على التماسك الأسـري بدلاً من الدخول في المنطقة السوداء و هي الطلاق الفعلي، ولكن تكمن المشكلة عند جمود العلاقة الزوجية عند هذه المرحلة، وكلما ز ادت مدة الجمود كلما أصبح من الصعب العودة إلى المرحلة السابقة، ويكون كلاً مـن الزورجين اعتـاد على هذا و أصبحت نمط وأسـلوب الحيـاة، وقتهـا تكون هذه هـي المشكلة الحقيقية.

وقد هدفت رشا محمود (ب ا • ب) في در استها بعنو ان "بعض المتغيرات النفسية

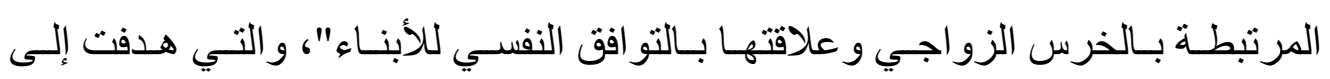


التعرف على الخرس الزواجي بين الأزواج ومدى علاقته بـالتو افق النفسي للأبنـاء،

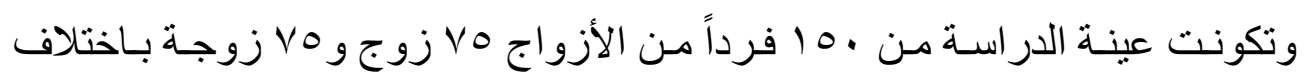

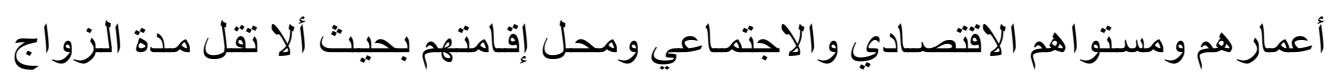

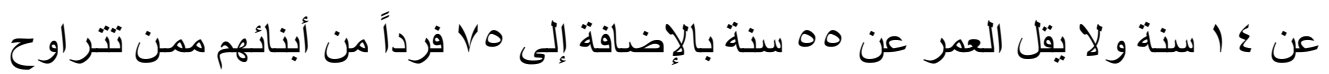

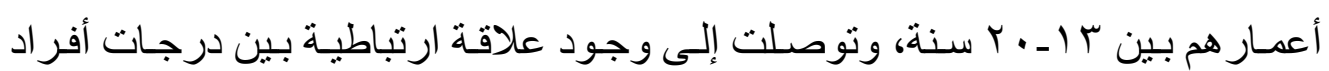
العينة على مقياس الخرس الزواجي ودرجاتهم على مقياس التوافق النفسي للأبناء.

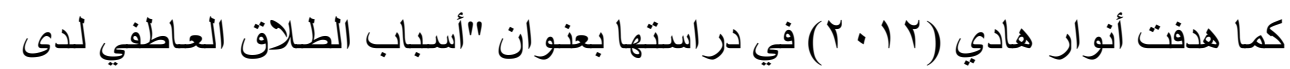

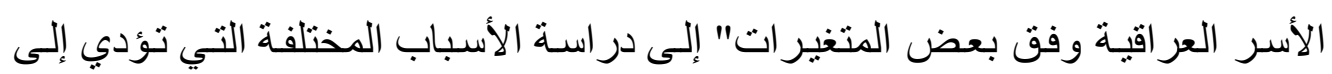

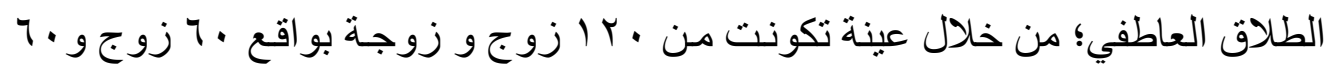

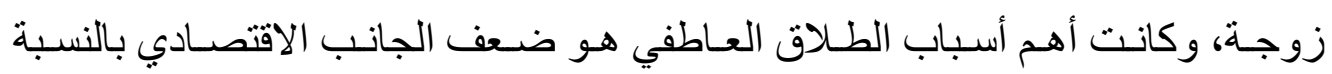
للزوجة، وضعف الحب أو الجانب العاطفي بالنسبة للزورج.

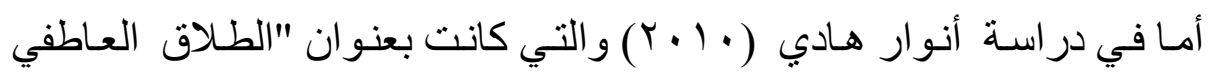
و علاقته بفاعلية الذات لدى الأسر في مدينة بغداد"، وقد اختارت عينة مقصودة مكونـة لونة

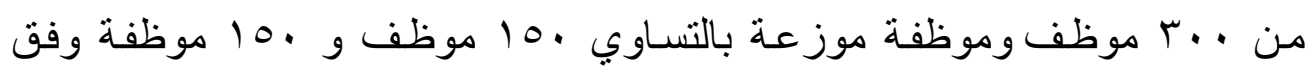

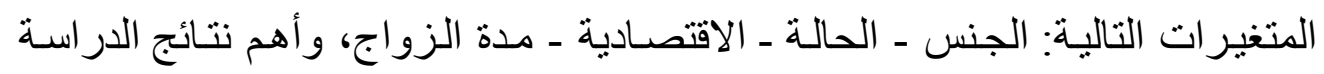

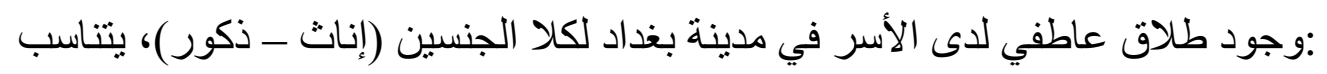

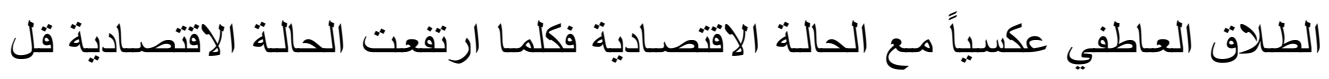

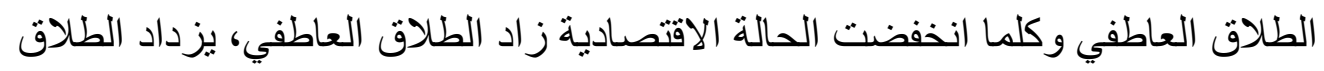
العاطفي كلما قلت مدة الزواج ويقل كلماز زادت مدة الزواج. وفي در اسة جيفالد Gevald, (2010) بعنوان "إدر الك التكيف الثخصسي و العائلي لأطفال الأسر ذات الو الد الوحيد"، هدفت إلى الكثف عن العلاقة بين الأسر التي يغيب

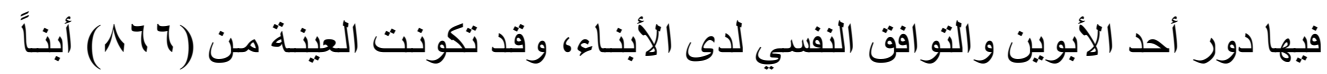


تراوحت أعمار هم ما بين (9- Y I ) سنة من كلا الجنسين ، وقد أظهرت نتائج در استها: أن أبناء الأسر التي يغيب فيها دور أحد الأبوين أقل في تو افقهم النفسي من أبناء الأسر

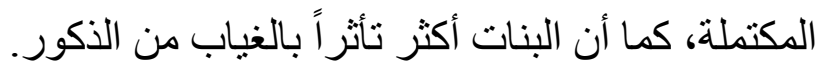

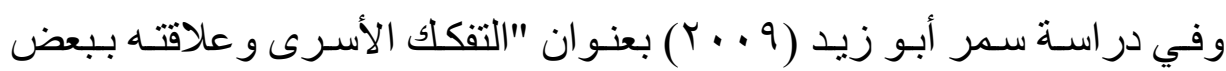

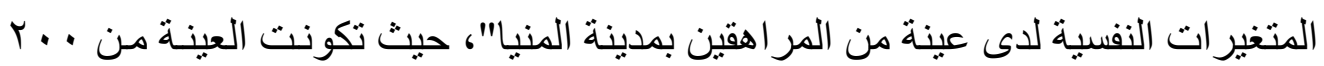

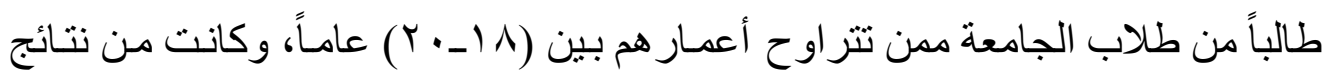
الدراسة وجود علاقة ارتباطيه بين التفكلك الأسري وبعض المتغير ات النفسية لدى عينـة

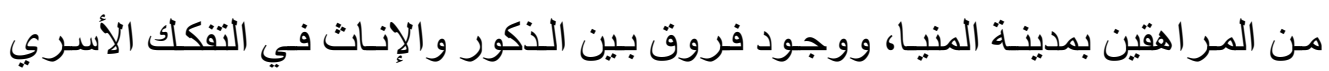
لصالح الإناث.

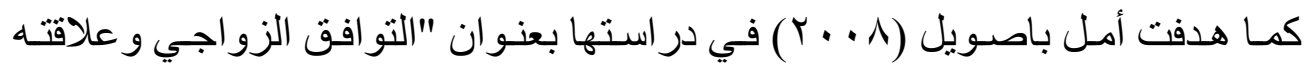

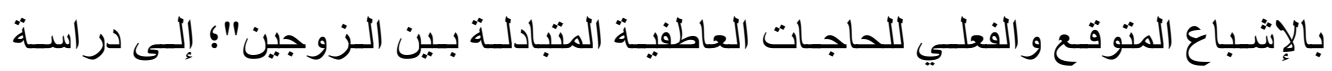
الحاجات العاطفية التي يتوقعها كل طرف من الأخر في العلاقة الزوجية في الأسرة

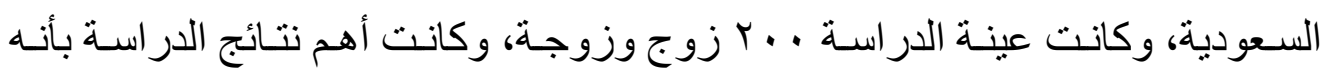
تختلف درجة الانسجام في كل من الإشباع المتوقع و الإشباع الفعلي للحاجـات العاطفية بين الزوجين باختلاف مستويات كل من: عمر الزوجين، تعليم الزوجين، عدد الأبناء، جنس الأبناء، درجة القر ابة بين الزوجين، دخل الأسرة. وفي در اسة رانيا عبد المجيد (ך + . †) بعنوان "الطلاق العاطفي كما يدركه الأبناء في مرحلة الطفولة المتأخرة و علاقته بالعدو انية"، و التي تكونت العينة من ـ م 10 طفل وطفلة

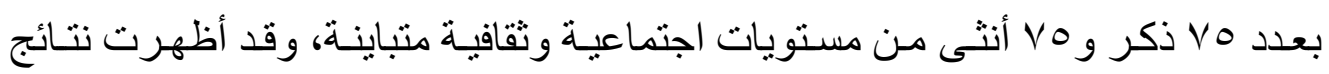
در استها وجود علاقة بين الطلاق العاطفي و السلوك العدو اني لدى الأبناء، ووجود فروق بين الذكور و الإناث في السلوك العدو اني لصالح الذكور. 
أمـا در اسـة عبد العزيز الجهني (0 ، . ب) بعنوان "الخلافات الزوجيـة في المجتمع السعودي من وجهة نظر الزوجـات المتصـلات بوحدة الإرشـاد الاجتمـاعي"، فقد هدفت

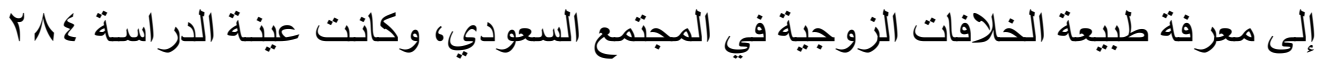
زوجةة، وقد كانت النتائج كالتالي: أن الخلافات التي تحدث مـن الزوج هي فتور في علاقته العاطفية مع زوجته، عدم إظهار الزوج لمثـاعره الايجابيـة تجـاه زوجته، غياب الزوج عن المنزل أو السهر خارج المنزل باستمرار، أن الزوج بغضـب بسر عة، عدم إنفاق الزوج على الأسـرة، أمـا الخلافات التي تحدث من الزوجـة هي عدم شـعور ها بالأمان مع الزوج، الثك في سلوكه، فتور في علاقتها العاطفية مـع الزوج، عدم تقبلها زواجه بأخرى، علاقتها بأهل الزوج سيئة. وقد أجرى ارينسافت و آخرون Ehrensaft et al., در اسة بعنو ان "انتقال عنف الشريك بين الأجيال"، على عينة تكونت من (r §o) طفلاً تم اختيـار هم بشكل عشو ائي، حيث تبين أن مشاهدة العنف بين الوالدين بعد من عو امل الخطورة المسببة في ممارسـة هؤلاء الثباب للعنف في علاقاتهم الحميمة.

ScNeal \& أظهـرت در اسـة طوليـة تتبعيـة أخرى أجر اهـا ماكنيل و أمساتو بعiو ان "العنف الزوجي للو الدين"، وكانت در اسة طولية اعتمدو ا فيها

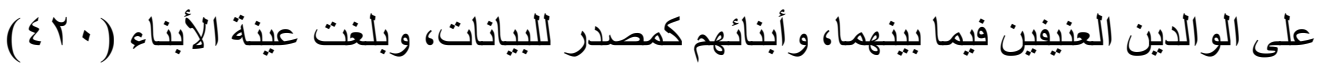
ابناً تر اوحت أعمار هم بين لو 9 ا سنة، وكان من أهم نتائج الدر اسة أن العنف ينتقل من جيل لآخر داخل الأسرة الواحدة، كما أن الآثار السلبية لمشاهدة العنف بين الآبـاء تستمر حتى بلوغ مرحلة الرشد. كما أظهرت در اسـة محمد بيومي (2000) بعنو ان "تأثير المنـاخ الأسـري على الصـة النفسية للأبنـاء" وكانت عينـة الدر اسـة مكونـة من 200 مر اهق ومر اهقة منهم 120 مر اهقاً و 80 مر اهقة، وكان من أهم النتائج ارتباط الصحة النفسية إيجابياً بالمناخ 


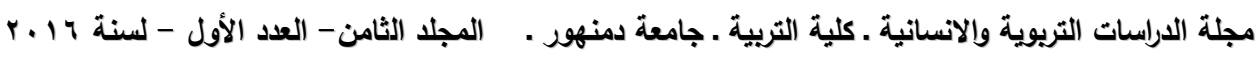

الأسري بأبعاده الستة التي تضمنها المقياس وهي: الأمان الأسري و التضحية و التعاون الأسري، ووضوح الأدوار وتحديد المسؤوليات الأسرية، والضبط ونظسام الحياة الأسرية، وإثباع حاجات أفر اد الأسرة، و الحياة الزوجية للأسرة، كما بين وجود ولئد علاقة موجبـة بين المنـاخ الأسري العام والصحة النفسية للأبناء ببعديها السـلامة النفسية و التفاعل الإيجابي مع الحياة.

\section{بـ الاتزان الانفعالي لدى الأبناء Emotional Stability:}

يتمثل الانفعال Emotion في كل ما ينتاب الفرد من حالات وجدانية كالحب أو الكره أو الحزن أو الغضب أو الغيرة أو السرور أو القلق أو النفور، كمـا يتصف التهن الانفعـال بحدوث استجابة فسيولوجية على درجة من الثدة تتضح في الارتفاع الدفاجئ لضربات

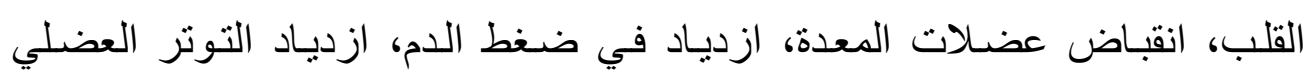

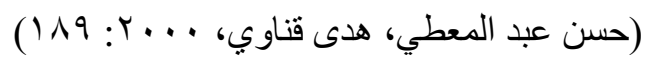

أما الاتزان فهو الوسط الذي يمثل العدل بين الأثشياء جميعاً ، فهو ليس قانوناً للوجود

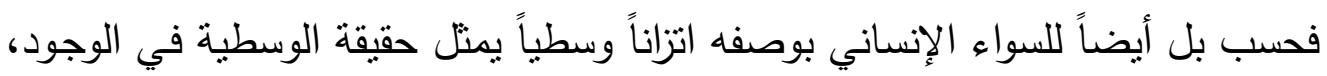

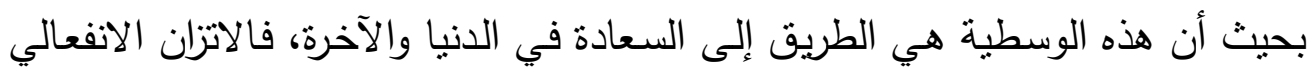

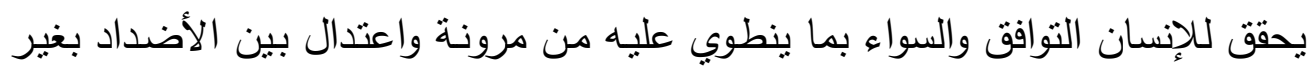

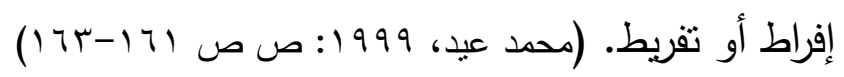

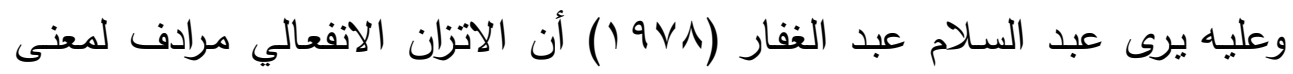
الوسطية وأن مرونة الثخصية من مظاهر هذه الوسطية ، ويقصد بالوسطية الاعتدال

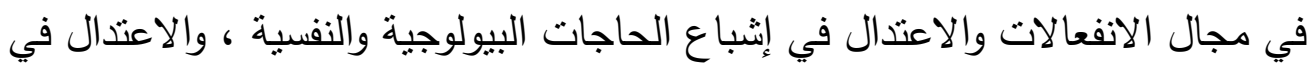
تحقيق قيمة أو تحقيق ذلك الجانب من الثخصية الذي أهمله الآخرون وهو الجانب

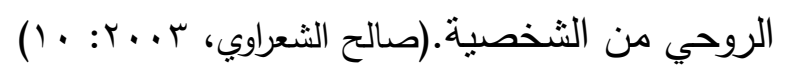

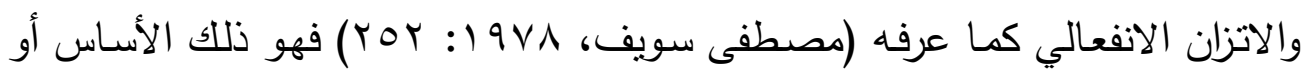

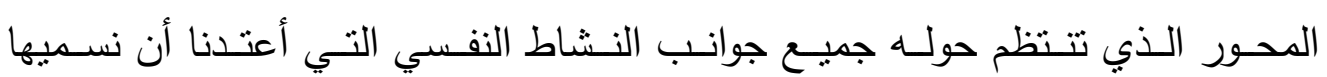


بالانفعالات أو الثقلبات الوجدانية من حيث تحقيقها لثعور الشخص بالاستقرار النفسي

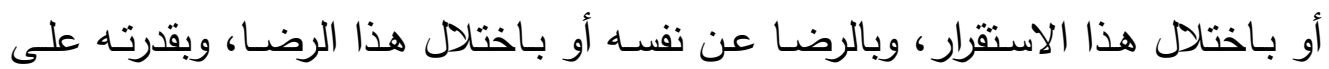
التحكم في مشاعره أو بانفلات زمام السيطرة من يديه.

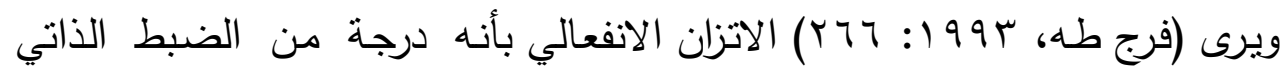

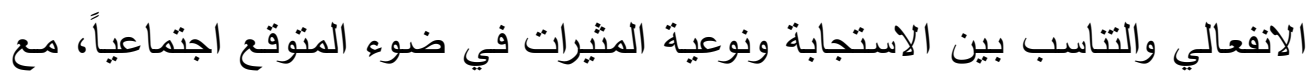

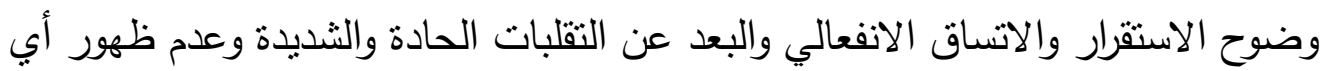

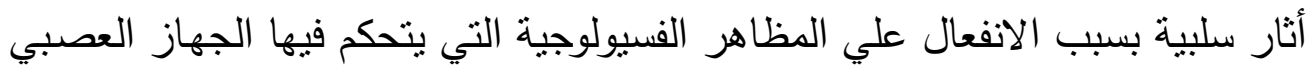
المستقل مثل التغيرات الحشوية في الجهاز الهضمي أو الجهاز الدوري أو الجهاز النفسي أو في السلوك. كما يعني الاتزان الانفعالي التحكم والسيطرة على الذات، فإذا نظرنا إلى الاتزان

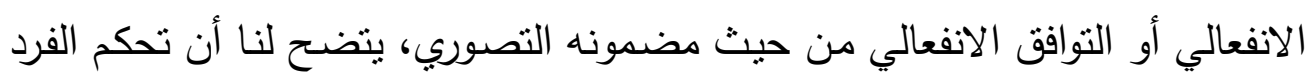

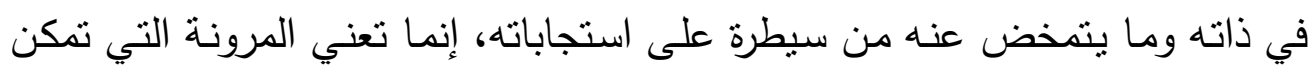
صاحبها ليس فقط من مواجهة المألوف من المواقف، بل الجديد منها. (سامية القطان، (0-4: : 1914 وقدرة الثخص على السيطرة على انفعالاته المختلفة، والتعبير عنها بحسب ما تقتضيه الظروف وبشكل يتتاسب مع المواقف التي تستدعي هذه الانفعالات.(سهير كامل، 1999 :

والتحكم والسيطرة على الانفعالات والتعامل بمرونة مع المواقف والأحداث الجارية منها

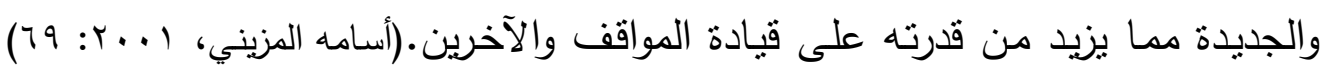
وللصحة النفسية علامات تتم عنها، ومؤشرات ترشد إليها، ودلالات تدل عليها، وتشير

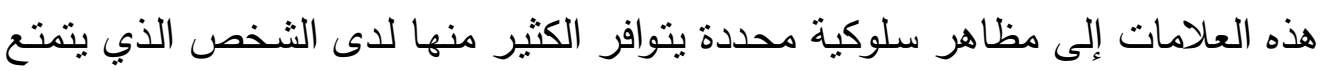

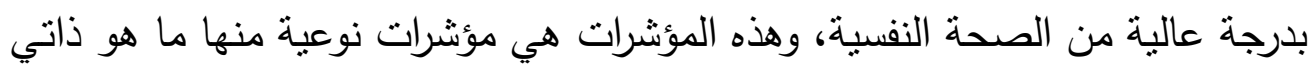

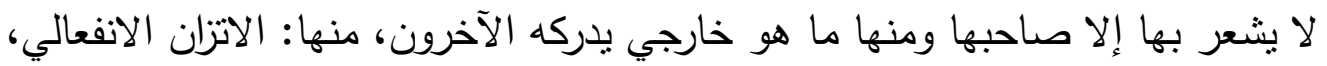

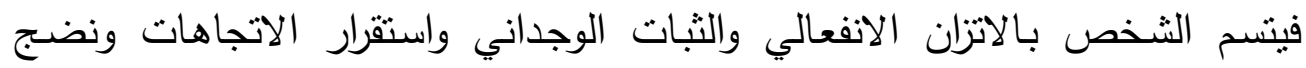
Doi: 10.12816/0044439 ד 
الانفعالات إلى حد بعيد ويعني وجود حالة من التماثل بين نوع المنبه ونوع الانفعال

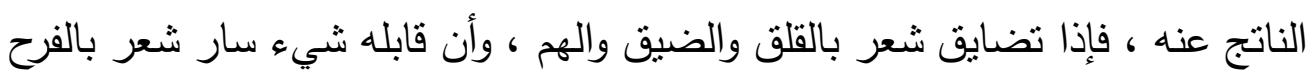

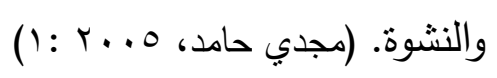

إن سمة الاتزان الانفعالي يتميز بها المتفوقون عقلياً وذلك لشعورهم بالطمأنينة، والأمن

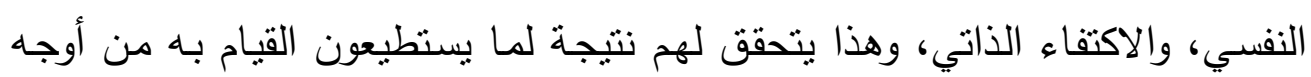

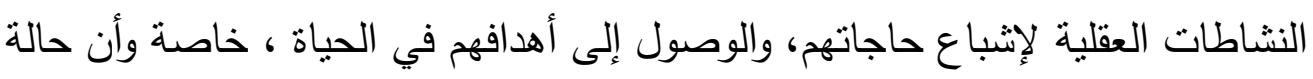

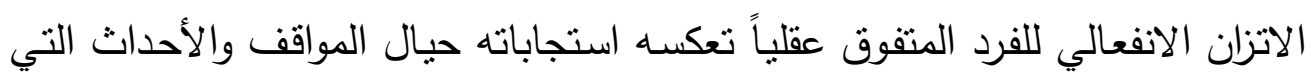

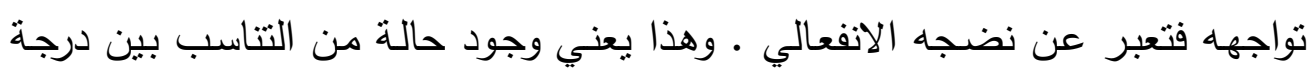

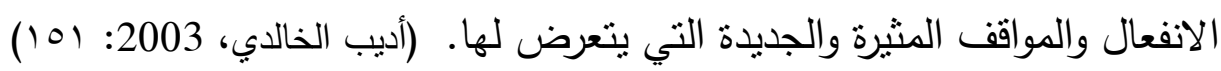
كما يتضمن الاتزان الانفعالي فكرة التوافق والتكامل بدرجاتها المختلفة، كما يتضمن

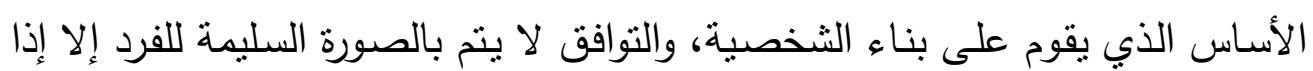

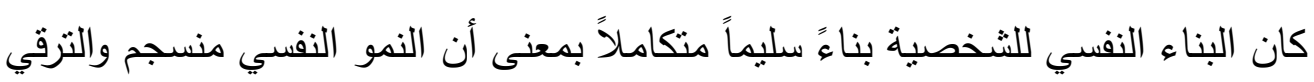

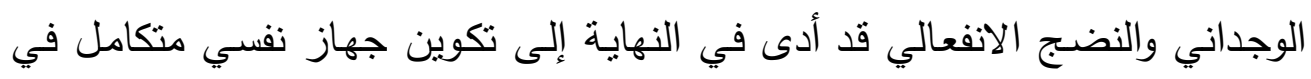

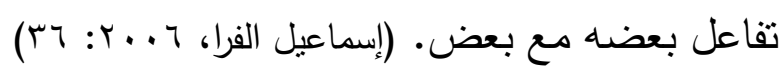

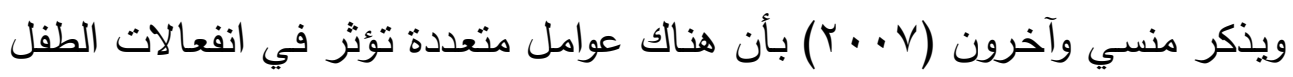

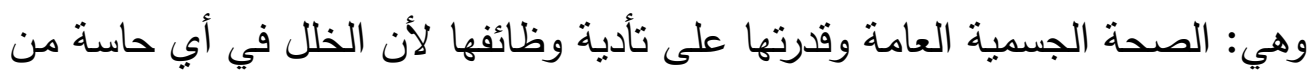
الحواس يؤثر في الاستجابة الانفعالية للطفل: ـ اضطر اب الجو الأسري: وهو له تأثثر سلبي على النمو الانفعالي للطفل. ـ فقد الو الدين أو أحدهما: وهو مـا ينعكس سلباً على انفعالات الأطفال وعواطفهم،

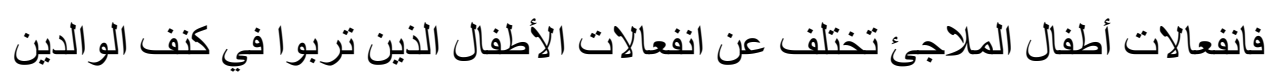
لأنهما يمدان الطفل بالدفء العاطفي ويوجهان انفعالاته بطريقة سوية. ـ التدريب و التعلم و النضـج: لهم تأثثير في سرعة نمو الانفعالات لدى الطفل. (ناصر

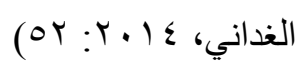


فالابن مخلوف اجتماعي يؤثر ويتأثر بالمحيط الذي يعيش فيه، وأن الظروف الضاغطة

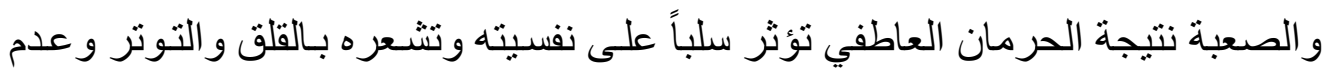
الثقة بالنفس؛ فيرى فرويد وهو من أو ائل الذين تحدثو ا عن القلق، أن القلق خبره انفعالية

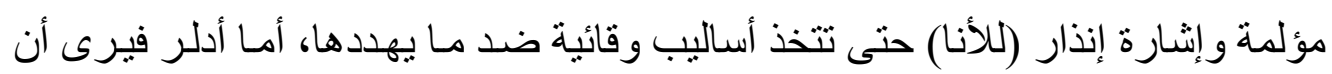
القلق النفسي ينشأ نتيجة شعور الابن بعدم الثعور بـالأمن وأن نوع التربية التي ينلقاهـا

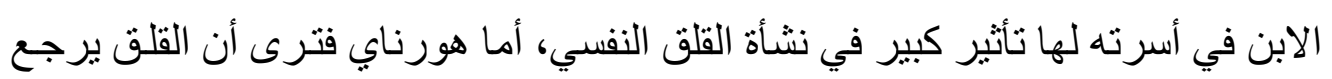

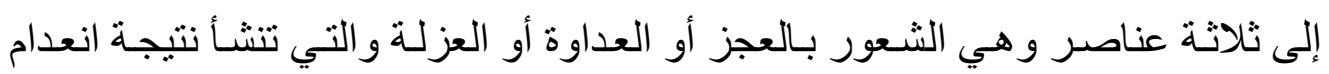
الدفء العاطفي وشعور الابن بأنه منبوذ ومحروم من العطف الأمر الذبي يجعل الابن

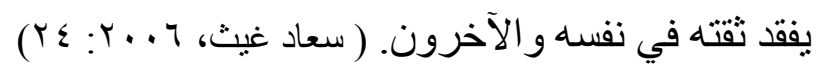

ويؤكد كـلا مـن كولمـان (Colman,1970)، وأيزنـك (Eysenck,1972) أن العصسابية

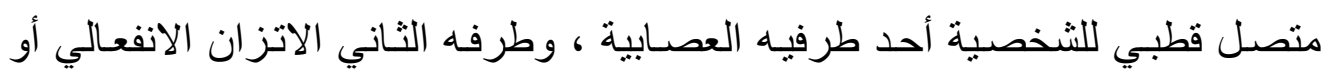

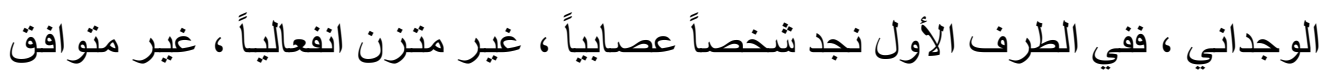

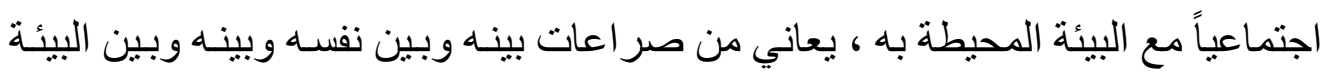

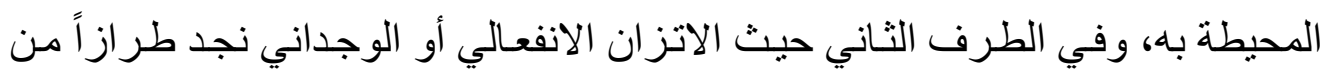

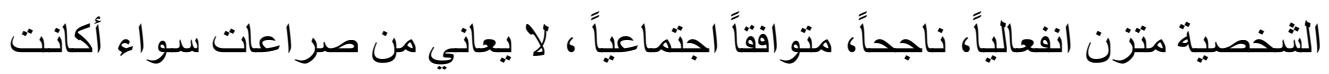

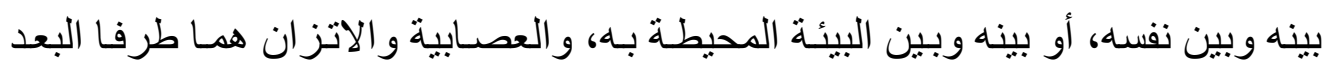
ويقع في المنتصف غالبية الأفر اد. (Colman,1970: 666, Eysenck, 1972: 325) ولقد قام ناصر الغداني (ع ( ب ب) بدر اسة بعنوان "أساليب المعاملة الو الدية كما يدركها

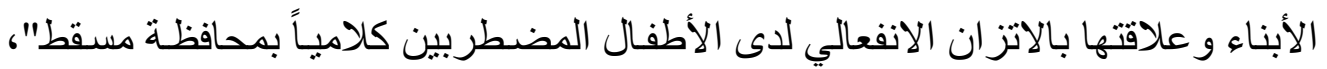

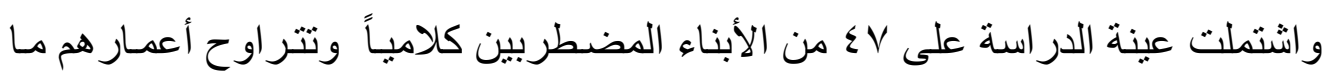

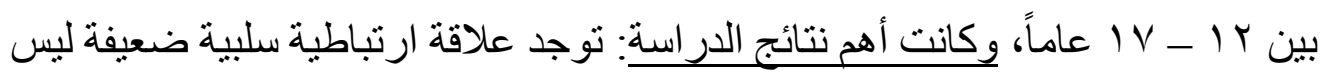

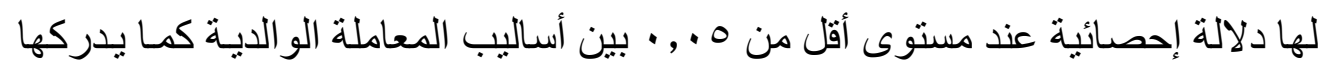




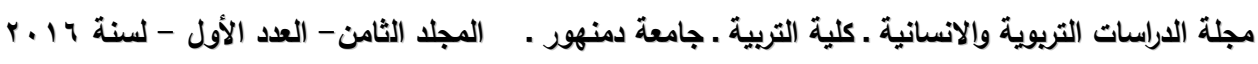

الأبناء و الاتزان الانفعالي، عدم وجود فروق في أسـاليب المعاملة الو الديـة كما يدركها الأبناء تعزى للمستوى الثقافي و الاقتصادي للأسرة.

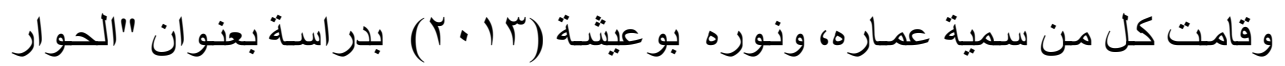

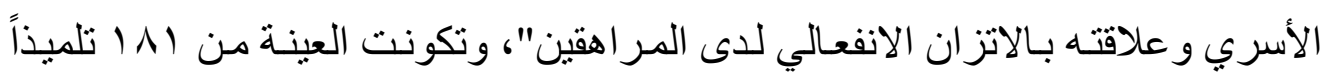

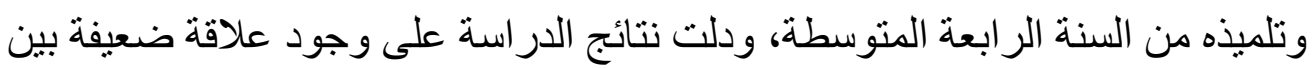

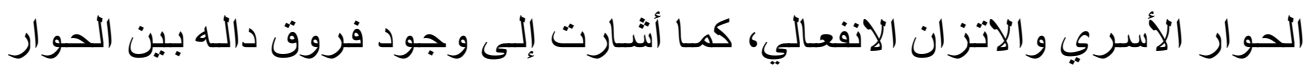
الأسري و الاتزان الانفعالي لصالح الإناث، وعلى وجود فرق دال بين الحوار الأسري و الاتزان الانفعالي لصالح الأسر التي عدد أفرادها (ه فما فوق).

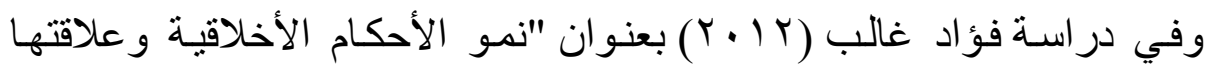

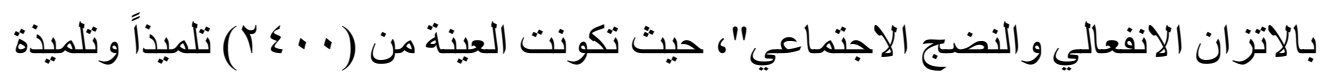

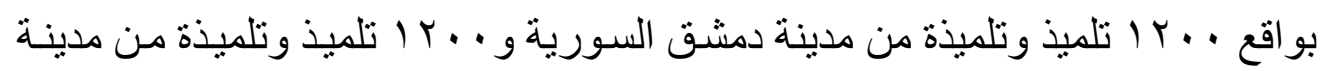
تعز بـاليمن، وكانت أهم النتائج: وجود علاقة ارتباطية بين نمو الأحكام الأخلاقيـة والاتزان الانفعـالي و النضـج الاجتمـاعي لدى أفر اد العينة، وجود علاقة بلة بين الاتزان الانفعالي و النضج الاجتماعي، عدم وجود فروق بين منوسطات الاتزان الانفعالي تبعاً

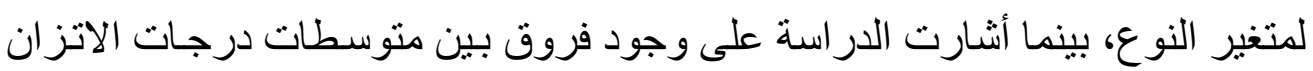
الانفعالي تبعاً لمتغير العمر. لبنيز.

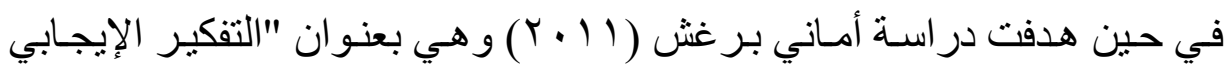
للآباء و علاقته بالتحصيل الدراسي و الاتزان الانفعالي و الدافعية للإنجاز لدى المر اهقين من ذوى صسوبات التعلم" إلى معرفة العلاقة بين التفكير الإيجابي للآبـاء و التحصيل

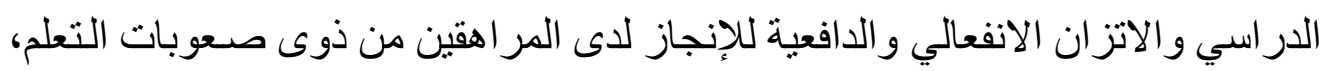

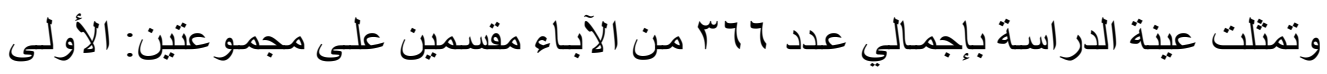

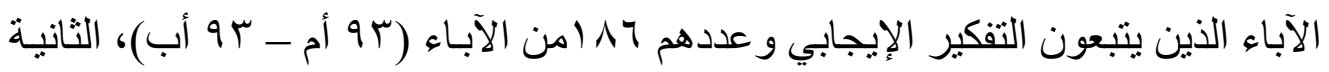

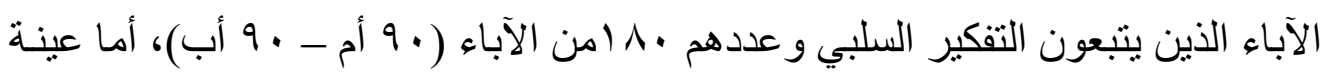
rq 
الأبناء فكانت أيضـاً نفس المجمو عتين: الأولى ب 9 مر اهقاً ممن ينتمون لآباء يتبعون

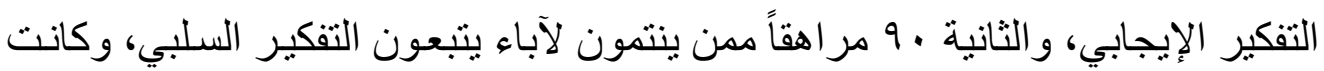
أهم النتائج: وجود فروق في الاتزان الانفعالي بين من ينتمون إلى آباء يفكرون بطريقة

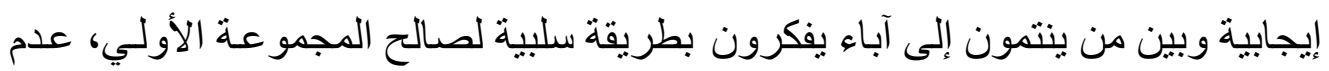

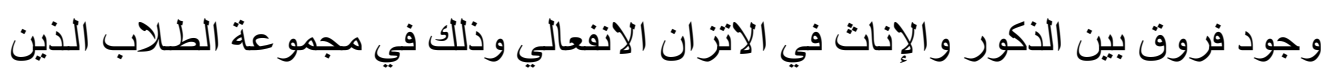
ينتمون إلى آباء يفكرون بطريقة سلبية. وقد توصلت نانسي محمد (1) • ب) في دراستها بعنوان "أساليب المعاملة الوالديـة

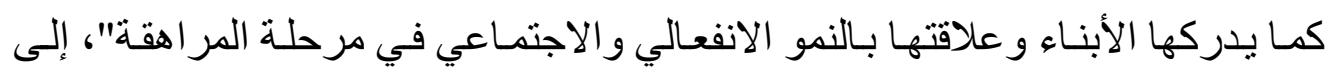

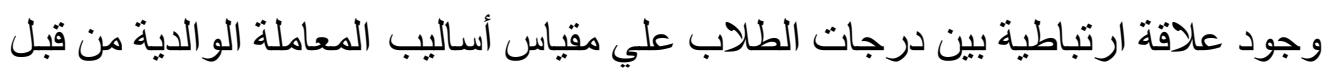

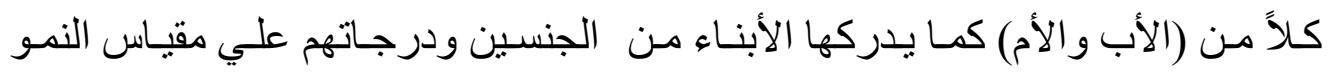

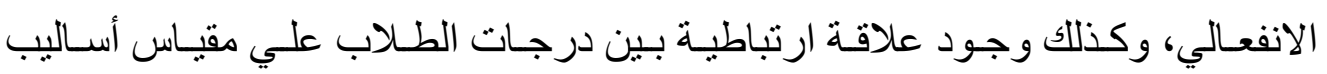

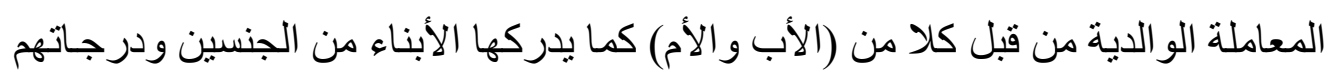
علي مقياس النمو الاجتماعي، ووجود فروق بين منوسطي درجات الإناث و الذكور في جميع أبعاد مقياس النمو الانفعالي (الاتزان الانفعالي، الحساسية الانفعالية، الاستقلال الانفعالي) بما في ذلك الدرجة الكلية للمقياس وذللك لصالح الإناث.

وتطرقت منى حمودة (^ . ㄷ) في در اسـة بعنوان "نمط الأسرة كمحدد لعلاقة

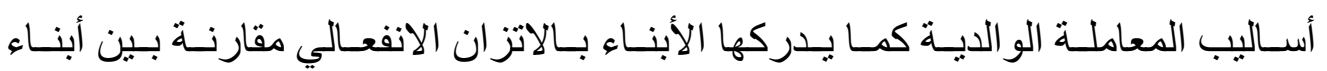

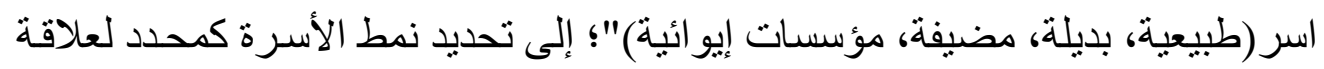

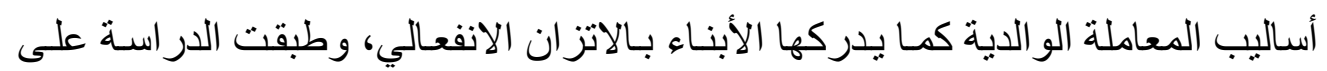

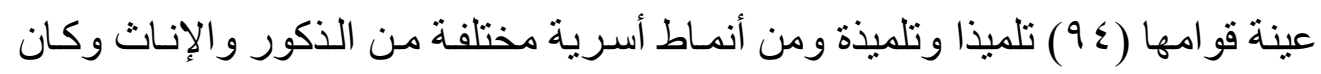

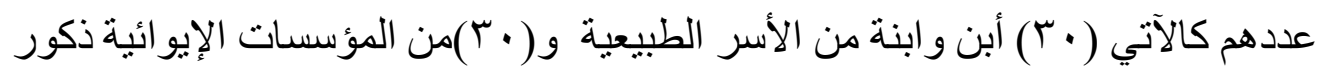

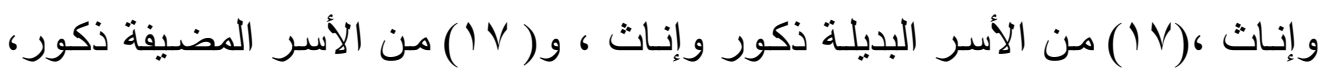

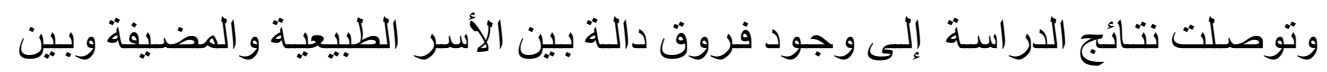
Doi: 10.12816/0044439 


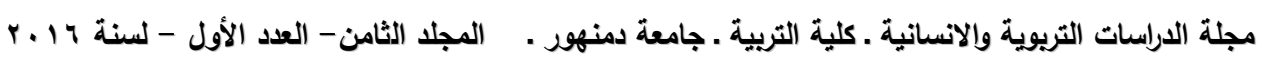

الأسر الطبيعية و المؤسسات الإيو ائية على أساليب المعاملة الوالديـة كمـا يدركها الأبناء لصالح الأسر المضيفة والمؤسسات الإيو ائية، كما توجد فروق دالة بين الأسـر الطبيعيـة و المؤسسات الإيوائية وبين الأسر الطبيعية والأسر البديلـة في متغير الاتزان الانفعـالي لصالح الأسر الطبيعية.

\section{- ثعليق على الدراسات السابقة:-}

\section{• أولاً الدراسات التي تثاولت الطلاق النفسي بين الزوجين:}

ـأكدت بعض الدراسـات على تأثير طبيعة العلاقات الأسرية على التوافق النفسي والمتغيرات النفسية لدي الأبناء كدراسة سمر محمد (9 ، . r)، ودراسة جيفالد (2010)

.Gevald,

- ركزت بعض الدراسات على أسباب الطلاق النفسي كدراسة أنوار هادي (Y I ـ ( ). ـ أكدت بعض الدراسات على العلاقة بين بعض المتغيرات النفسية المرتبطة بالخرس الزواجي والتوافق النفسي للأبناء كدراسة رشا محمود (r ا . Y).

- ركزت بعض الدراسـات على تأثير المناخ الأسري على صحة الأبناء النفسية كدراسة

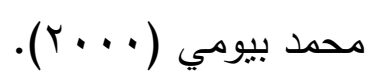

- ركزت بعض الدراسـات على الآثار السلبية لمشـاهدة العنف بين الآبـاء على تنشئة الأبناء كدراسـة ماكنيل وأمساتو (2004) \&cNeal \& Amato, ، ودراسـة ارينسافت

وآخرون (2005) (Ehrensaft et al.,

ـ اتفقت الدراسـات في تحديــ مسئولية المسـتوى الاقتصـادي والاجتمـاعي في الطـلاق العـاطفي، حيـث أنـه هنـاك تتاسـب عكسـي بـين ارتفـاع الطـلاق العـاطفي وانخفـاض

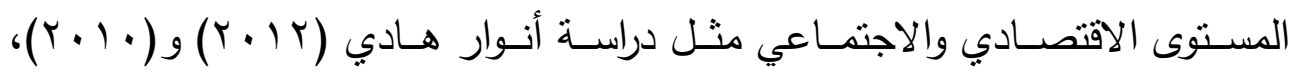
ودراسة أمل باصويل (1 . . ب). 
• •ثانياً الاراسات التي تتاولت الاتزان الانفعالي لدى الأبناء:

- اختلفت الدراسات في وجود علاقة بين أسـاليب المعاملة الوالديـة والاتزان الانفعالي

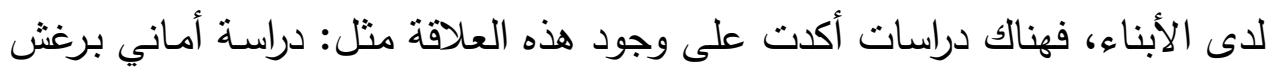

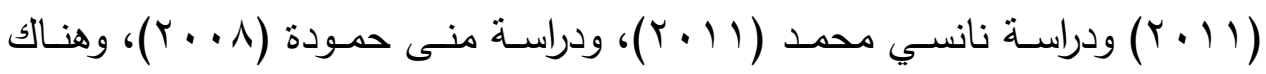

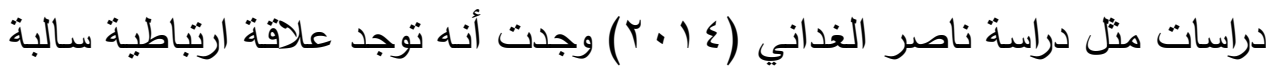
ضعيفة ليس لها دلالة إحصائية بين أساليب المعاملة الوالدية والاتزان الانفعالي.

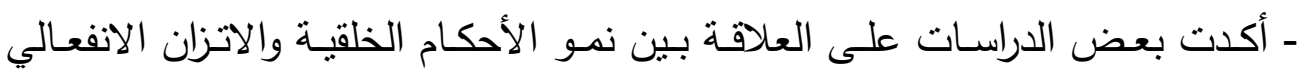
والنضج الاجتماعي كدراسة فؤاد غالب (r ا • r).

ـ أكدت بعض الدراسـات على العلاقـة بين الحوار الأسـري والاتزان الانفعـالي لدى

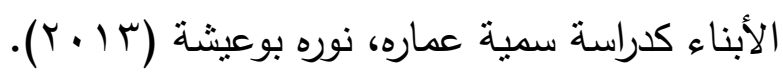

- اختلفت الدراسات في وجود فروق الاتزان الانفعالي لدى الأبناء بحسب النوع (ذكور

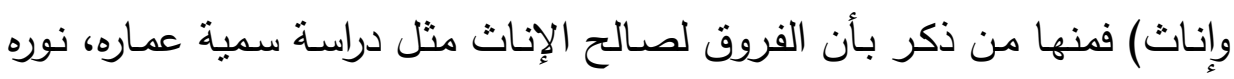

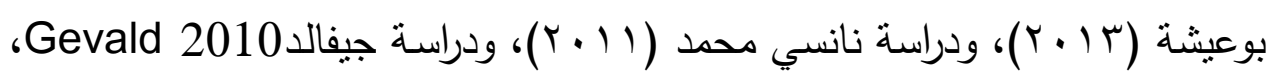

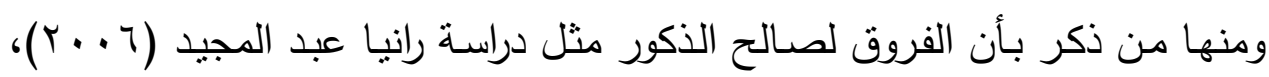

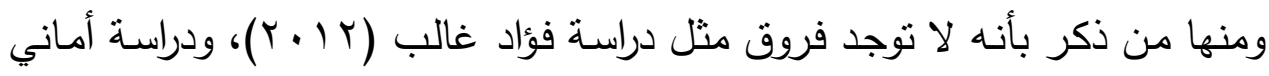

$$
\text { برغش (1) (1) (ب). }
$$

فروض الدراسة :

• توجد علاقة دالـة إحصـائياً بين الطلاق العاطفي عند الزوجين و الاتزان الانفعالي للأبناء. - نوجد فروق دالة إحصائياً في الاتزان الانفعالي لدى الأبناء بحسب النوع (الذكور

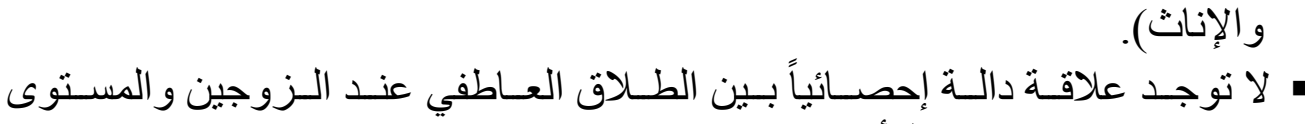
الاجتماعي الاقتصادي للأسرة. 


\section{المنهج المستخدم في الاراسة :}

قام الباحث باستخدام المنهج الوصفي (الارنباطي ـ المقارن).

العينة : نم اختيار عينة الدراسة من المجتمع الأصلي لددرستي أحمد عرابي الابتدائية

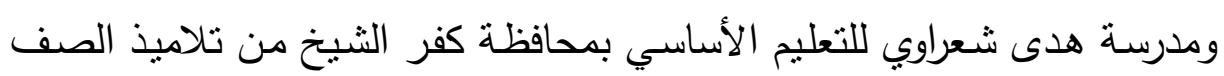

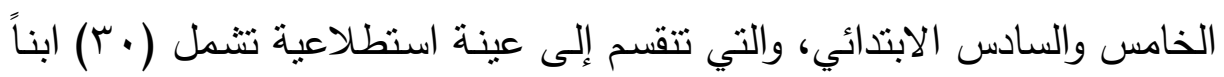

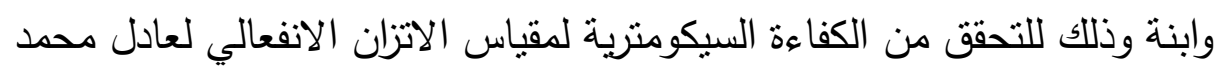

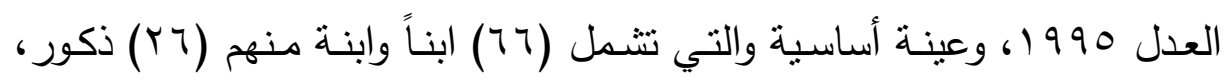

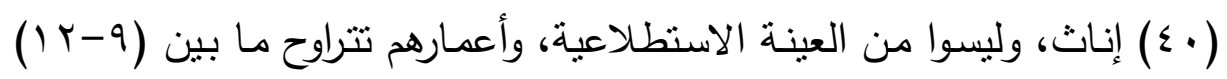

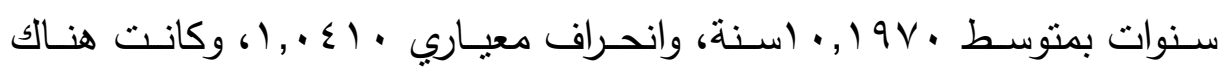
شروط في اختيار العينة على النحو التالي: 1- أن يكون كلا الوالدين على قيد الحياة.

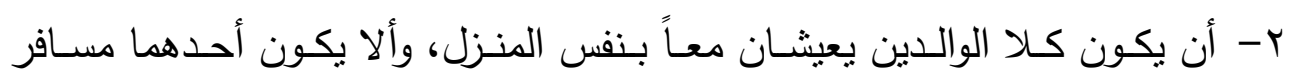

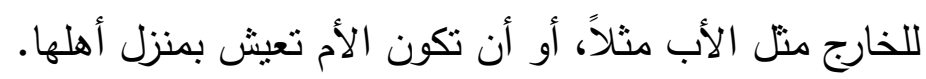
r- أن يكون الطفل يعيش بمنزل أبويه، وليس عند أحد الأقارب.

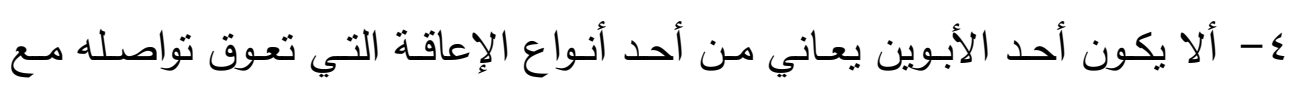
الأسرة، كالإعاقة البصرية. ه- ألا يكون الأب عاطلاً عن العمل. الإعنه 7- أن يكون الزوج متزوج من زوجة واحدة.

وقد نم اختيار العينة بناء على الثروط السابقة من خلال تطبيق استمارة البيانات

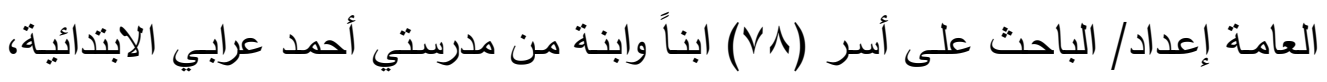

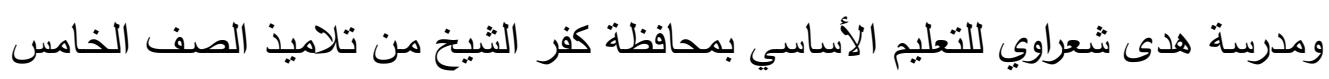
والسادس الابتدائي، وقد تم اختيار عدد (77) أسرة ممن تتطبق عليهم الثروط، وتم لأنم

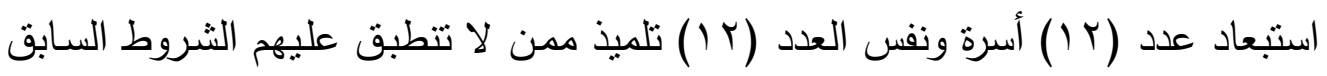
ذكرها. 


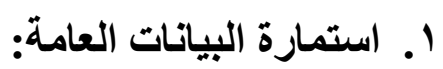

أُعِدَتْ الاستمارة من قبل الباحث بهدف تحديد المتغيرات المستقلة موضوع الدراسة، وبالتالي حجم العينات المناسبة وفقاً لعدد المتغيرات وتشمل: الحالة الاجتماعية

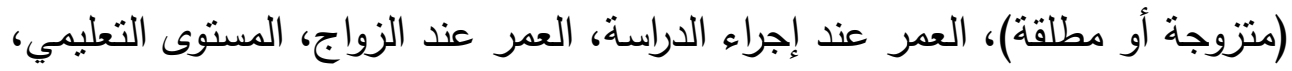

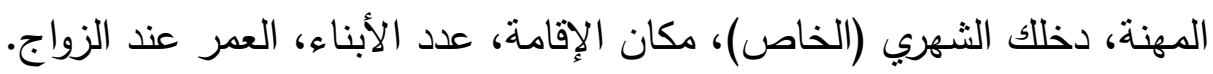
r.استمارة المستوى الاجتماعي الاقتصادي للأسرة :

إعداد/عبدالعزيز الشخص (ع ا م ب):

أعد مقياس جمع البيانات عن الحالة الاجتماعية/ الاقتصادية لبعض الأسر في ضوء

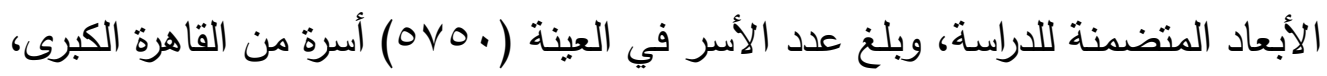

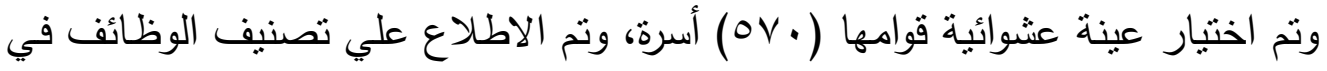
بعض المصالح الحكومية والجهاز المركزي للتنظيم والإدارة وحساب متوسط دخل الأسرة

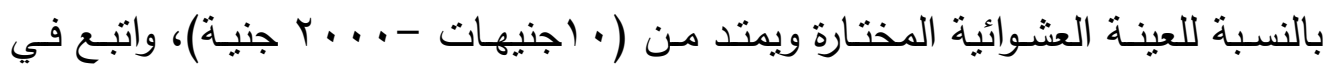

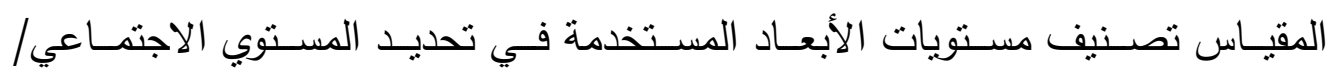

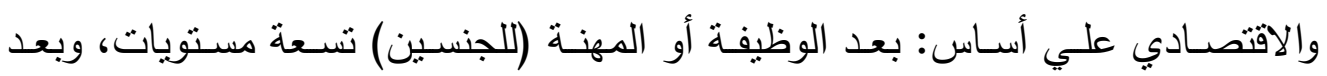

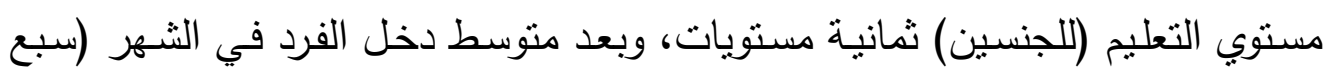
فئات).

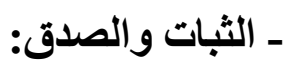

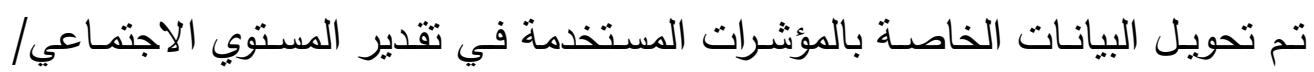
الاقتصادي إلي تقديرات رقمية وذلك بإعطائها درجات نساوي رقم المستوي الموجود بها،

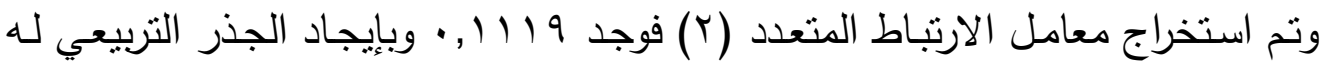

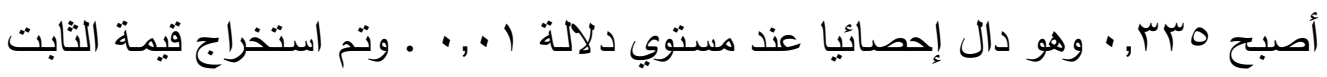

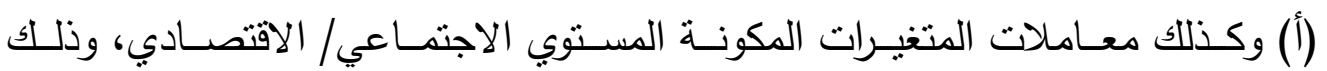


باستخدام طريقة المتغير الوهمي Dummy Variable حيث لا تدعو الحاجـة إلي استخدام محك خارجي في حساب المعادلة النتبؤية.

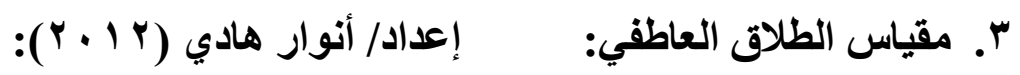

لقد قام الباحث بتبني مقياس الطلاق العاطفي والذي يتكون من وب فقرة، وقد خضع المقياس إلى الصدق والثبات، وتحسب الدرجة الكلية للمستجيب من خلال جمع الدرجات

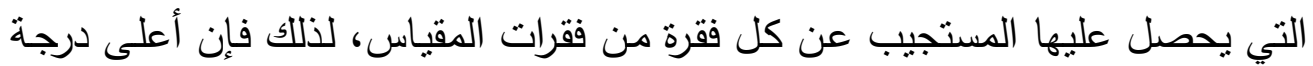

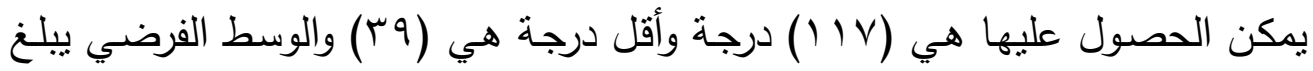

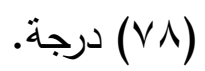

وقد تم حساب الكفاءة السيكومترية للمقياس بالصدق المرتبط بالمحك، حيث استخدم الباحث مقياس التوافق الزواجي إعداد/ عادل الأشول، وقد حصل الباحث على معامل باله

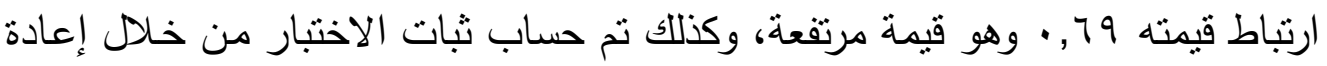

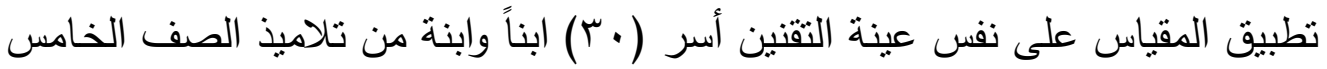
والسادس الابتدائي بعد أسبوعين من التطبيق الأول حيث وجد أن معامل الثبات ع ع, •.

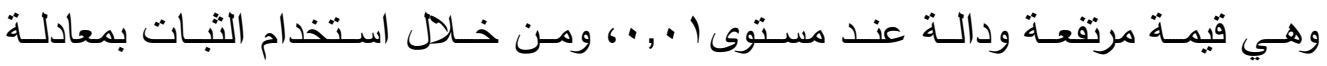
الفاكرونباخ حيث حصل الباحث على معامل ثبات قدرة VT, • وهو دال بما يكفي للتقة ودنة في ثبات المقياس. ؛ .مقياس الاتزان الانفعالي (إعداد/ عادل محمد العدل، ه9 9 (1)): يتألف المقياس في صورته النهائية من (17 (1) ) عبارة يجيب عليها المفحوص بنعم أو لا،

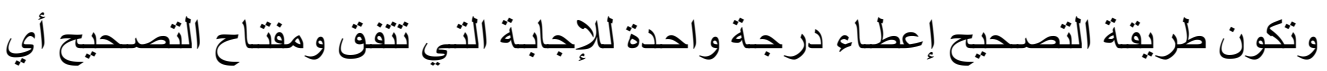
تتراوح الدرجة مـا بين ( ــ ا (1)). و الفرد الذي يحصل على درجة مرتفعة على هذا

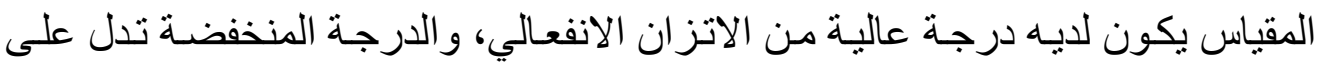
انخفاض الاتز ان الانفعالي. 
وقد قام الباحث بعمل صدق وثبات لمقياس الاتزان الانفعالي على عينة مكونـة من

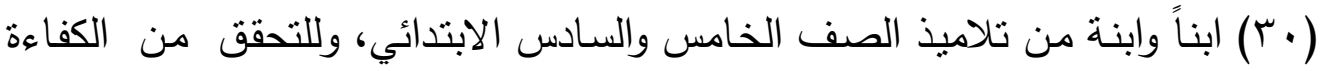
السيكومترية للمقياس تم حساب الصدق باستخدام طريقة صدق المحك لمقياس الاتزان

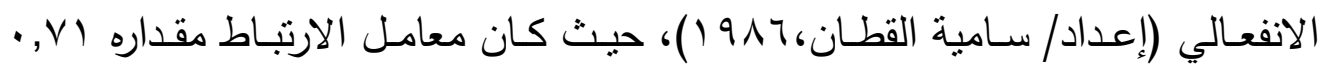
بدلالة إحصائية ا ب,.•. وتم استخدام طريقة معامل ألفا - كرونباخ على نفس العينـة الاسنطلاعية (·ץ) ابنـاً وابنـة من تلاميذ الصف الخامس والسـادس الابتدائي؛ فبلغت

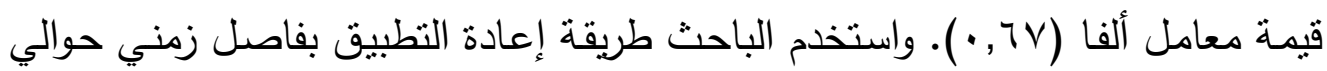

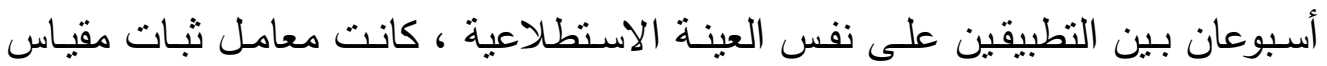

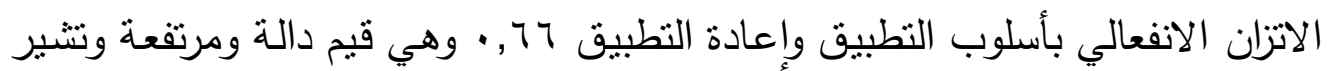
إلى ثبات المقياس وصداحيته في قياس الاتزان الانفعالي.

خطوات الدراسة: لإجراء الدراسة الميدانية قام الباحث بالخطوات التالية:

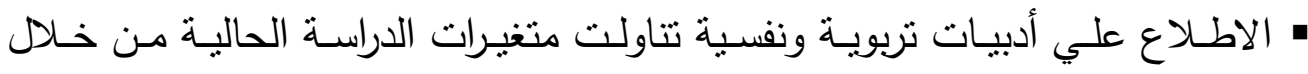
الإطار النظري والبحوث والدراسـات السـابقة، بغرض الإفادة منها في بنـاء الإطـار

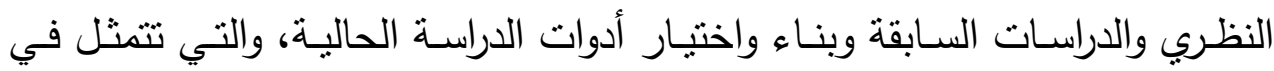
اسـتمارة البيانـات العامـة، واسـتمارة المستوى الاجتمـاعي الاقتصــادي للأسـرة

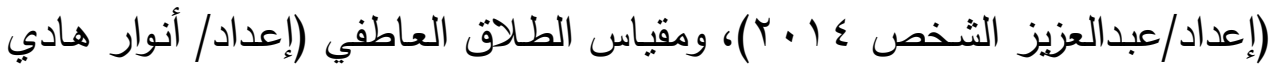
r ( ا r)، ومقياس الاتزان الانفعالي (إعداد/ عادل العدل، 990 ( ).

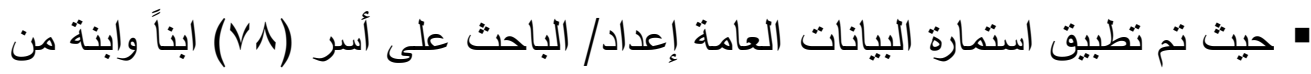

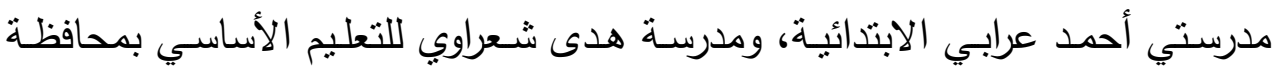

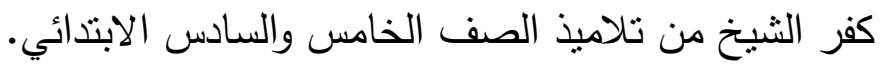
• تم تقنين أدوات الدراسـة الحالية والقيام بالتطبيق الاستطلاعي على أسر (•r) ابناً

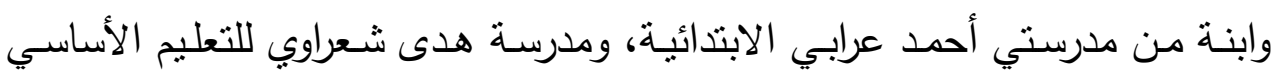
بمحافظة كفر الثيخ من تلاميذ الصف الخامس والسادس الابتدائي. 


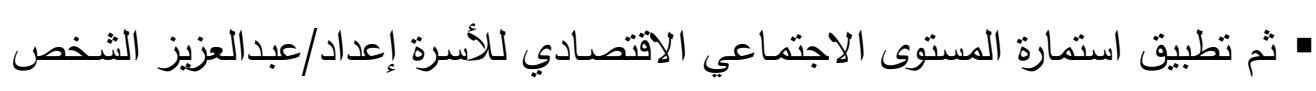

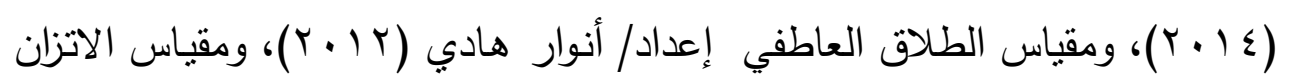

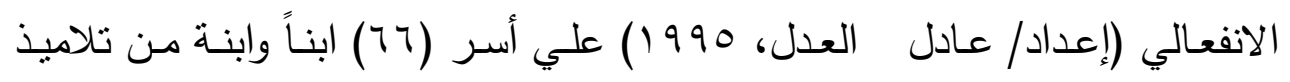
الصف الخامس والسادس الابتدائي.

• مناقثة النتائج وتفسيرها والتحقق من قبول أو رفض فروض الابند الدراسة. • تقديم بعض التوصيات والمقترحات التربوية في ضوء ما ما أسفرت عنه نتائج الدراسة.

$$
\text { نتائج الدراسة: }
$$

[1]

ينص الفرض على أنه: "توجد علاقة دالـة إحصائياً بين الطلاق العاطفي عند الزوجين والاتزان الانفعالي للأبناء".

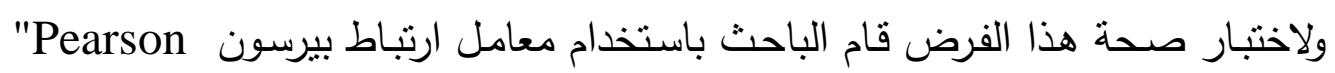

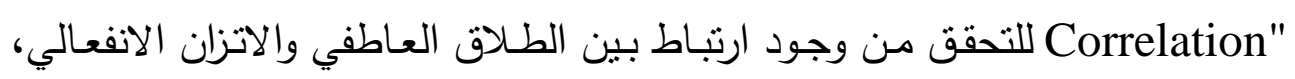
ويتضح ذلك في الجدول التالي:

جدول (1) : معاملات الارتباط بين الطلاق العاطفي والاتزان الانفعالي (ن=74)

\begin{tabular}{|c|c|c|c|c|}
\hline \multicolumn{4}{|c|}{ 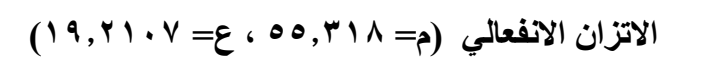 } & \multirow{2}{*}{ المتغيرات } \\
\hline الارتباط & الانحراف المعياري & |المتوسط & العدد & \\
\hline **, oro & 10,0VA & $V \varepsilon, 177$ & 97 & الطلاق العاطفي \\
\hline
\end{tabular}

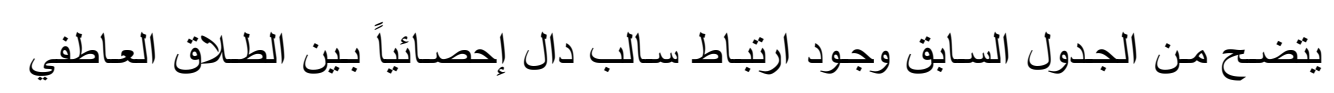
والاتزان الانفعالي، حيث كانت قيمة معامل الارتباط دال عند مستوى (1 .,. •). وتتفق هذه النتائج مع ما توصلت إليه بعض الدراسات السابقة في أنه يوجد ارتباط بين

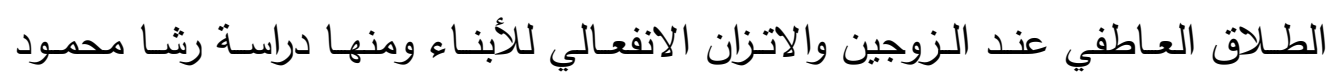




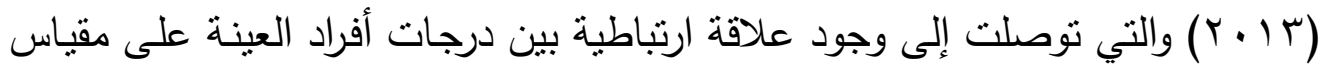

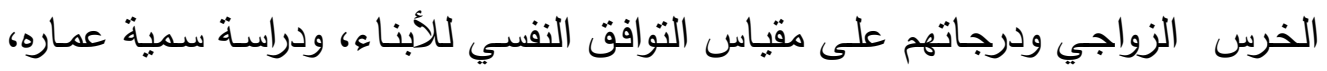

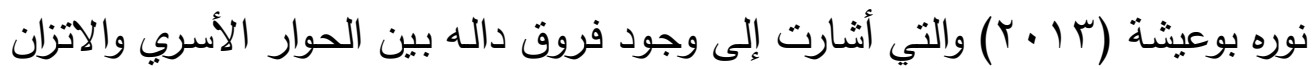

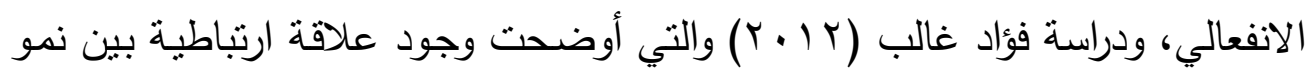

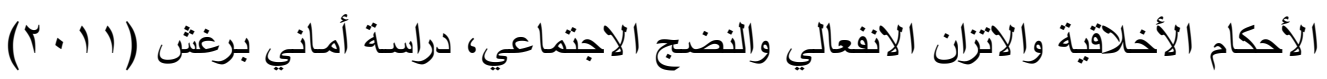

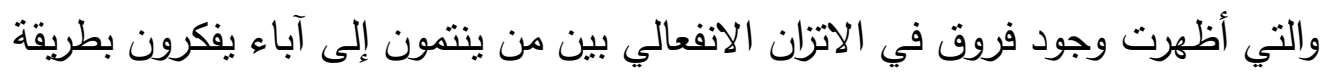

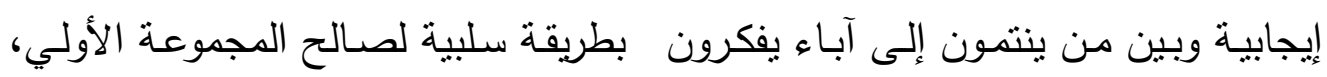

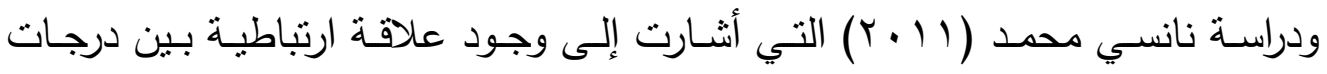

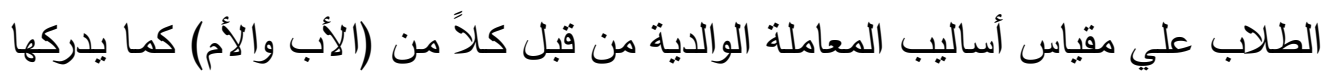
الأبناء من الجنسين ودرجاتهم علي مقياس النمو الانفعالي، ودراسـة جيفالد (2010) Gevald,

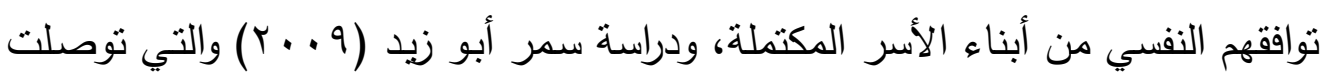

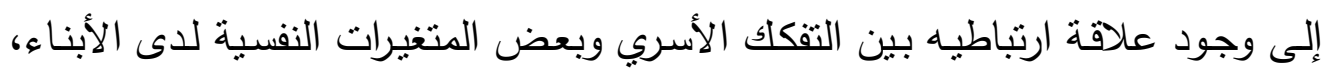
ودراسة مني حمودة (1 . . ب) والتي توصلت إلى وجود فروق دالة في متغير الاتزان

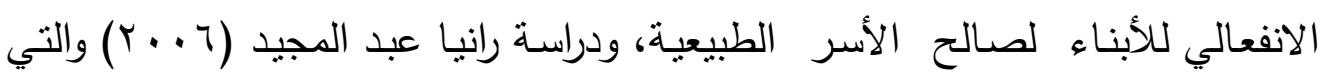

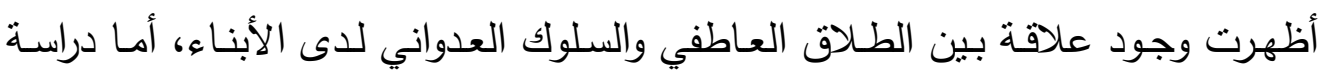
أجرى ارينسافت و آخرون Ehrensaft et al., (2005) فقد أظهرت أن مشاهدة العنف الفاهول بين الوالدين يعد من عوامل الخطورة المسبية في ممارسة هؤلاء الثباب للعنف، كما

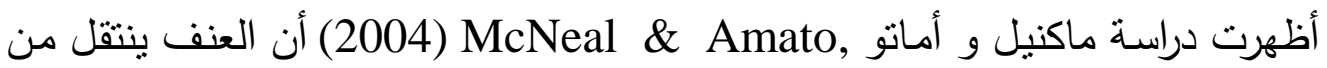
جيل لآخر داخل الأسرة الواحدة، وكذلك دراسة محمد بيومي (2000) والتي أظهرت

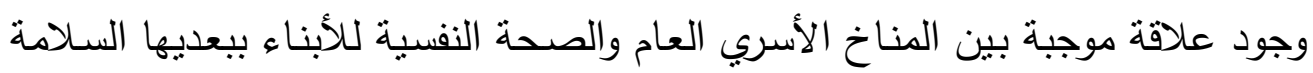
النفسية والتفاعل الإيجابي مع الحياة. 
وتختلف هذه النتائج مع نتائج دراسة ناصر الغداني (ع ا ـ ؟) والتي وجدت أنه توجد علاقة ارتباطية سالبة ضعيفة ليس لها دلالة إحصائية بين أساليب المعاملة الوالدية والاتزان الانفعالي.

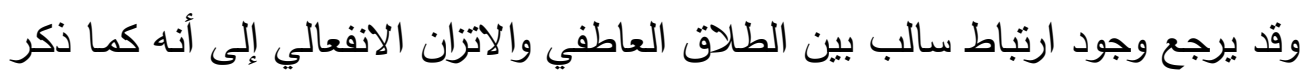

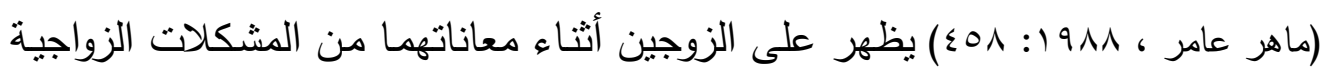

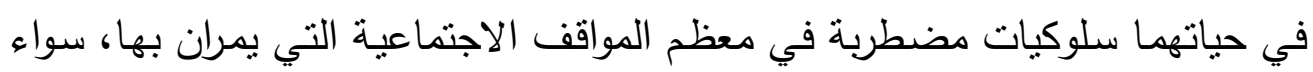

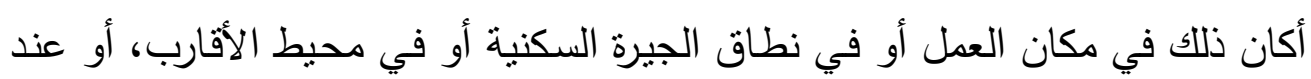
مزاولة أب نشاط عادي في حياتهما اليومية. وهو ما ينعكس بشكل مباشر في تأثيره على علاقتهما بأبنائهما، وبنفس الثكل عندما يشعر الأبناء بهذا التوتر الموجود بين الوالدين، وهو ما يؤثنر في سلوكياتهم واتزانهم الانفعالي. ولقد كثفت البحوث والدراسات أن الأطفال الذين يعانون اضطراباً في نمو شخصياتهر

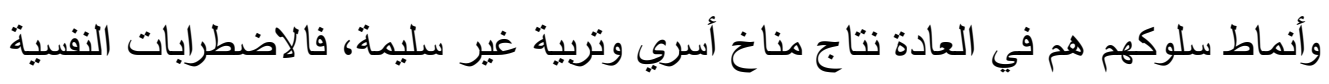

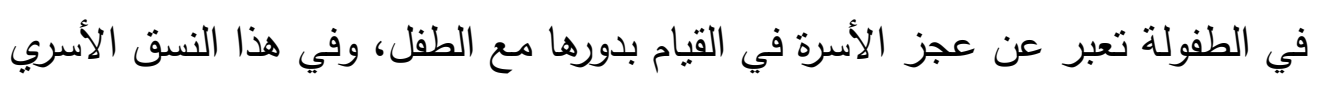

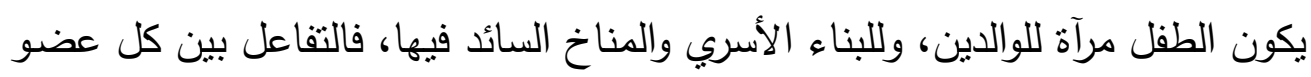

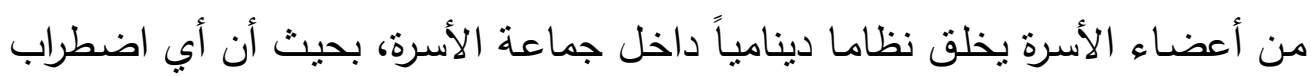

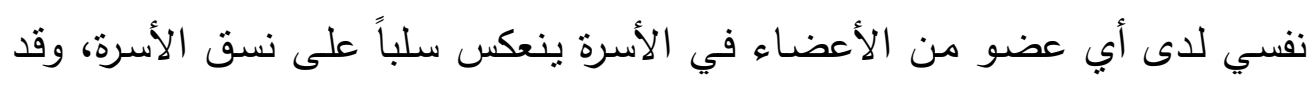

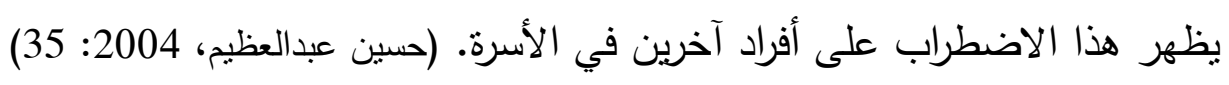
وقد تبين أن الأطفال في الأسر المضطربة زواجياً يعانون من ظروف اجنين اجتماعية

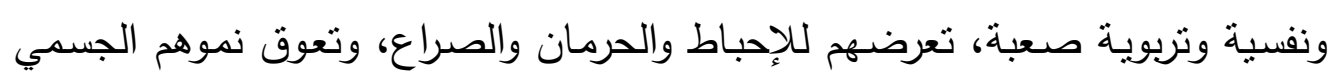

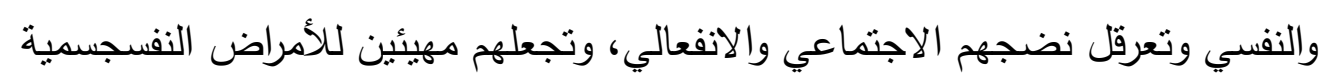

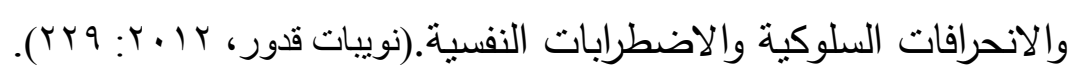




\section{[Yr] - نتائج الفرض الثاني :}

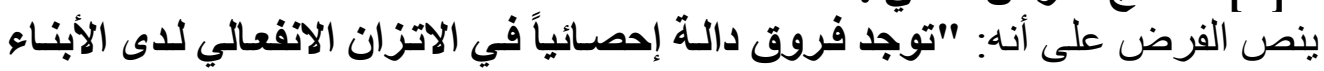

بحسب النوع (الذكور والإناث)".

و لاختبار صحة هذا الفرض قام الباحث بحسـاب متوسطي درجات الاتزان الانفعالي

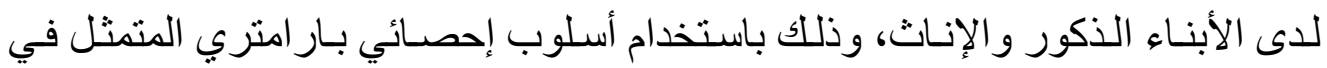
اختبار ت T- test للأزواج غير المرتبطة، وجاءت النتائج كما في الجدول (r): جدول (r) : اتجاه الفروق بين متوسطي درجات الأكور والإناث في الاتزان

\begin{tabular}{|c|c|c|c|c|c|c|c|}
\hline مستوى الدلالة & قيمة "ت" & ح.د & انحراف معياري & متوسط & العدد & المجموعة & المقياس \\
\hline \multirow{2}{*}{$\cdot, \cdot 0$} & \multirow{2}{*}{ Y,YTE } & \multirow{2}{*}{$7 \leq$} & $17,017 \mathrm{~V}$. & $\leq 9,19 r r$ & Y & ذكور & \multirow{2}{*}{ الانفتان } \\
\hline & & & 19,9Vrrr & $\bullet q, r \ldots$ & $\varepsilon$. & إناث & \\
\hline
\end{tabular}

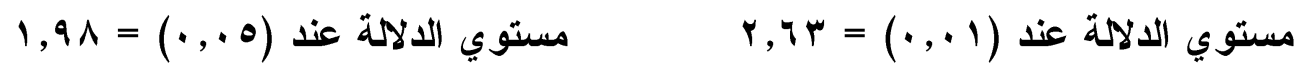

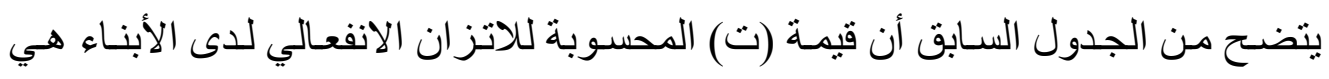

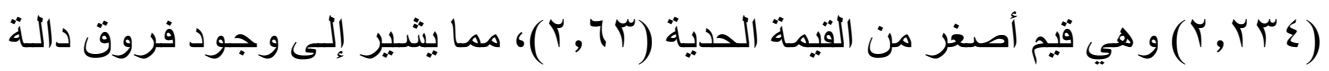

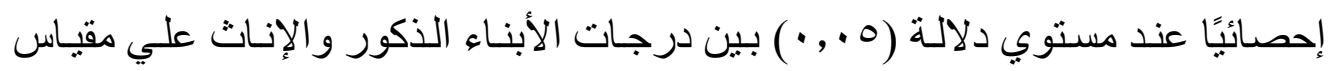
الاتزان الانفعالي لصالح الإناث، أي أن الإناث أعلى من الذكور في الاتزان الانفعالي. كمـا يوضـح الثـكل ( () التمثيل البيـني لقيم متوسطي درجـات الاتزان الانفعـالي لدى الأبناء الذكور والإناث علي مقياس الاتزان الانفعالي. 


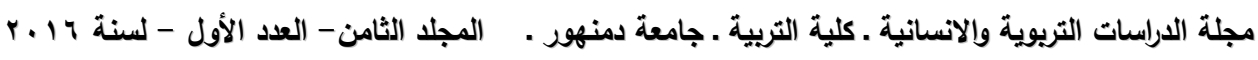

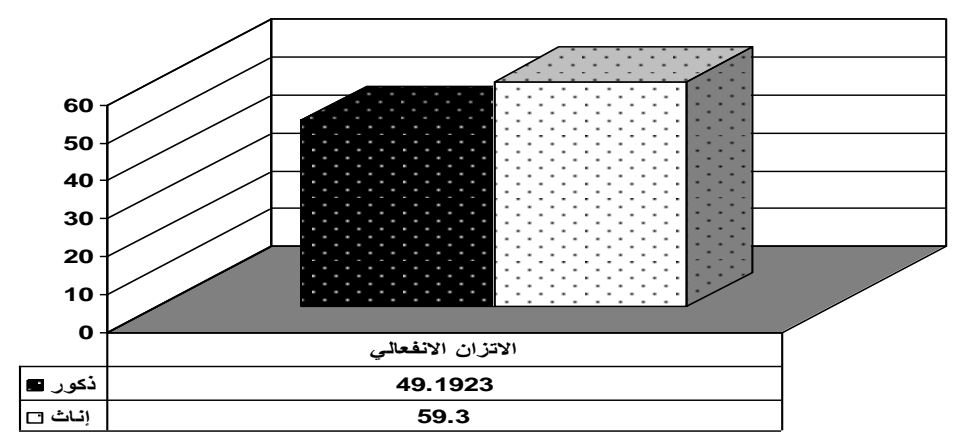

شكل (1 ) : التمثيل البياني لمتوسطي درجات الذكور والإناث في الاتزان الانفعالي

يتضـح من الثـل السـابق أن درجات الاتزان الانفعـالي لدى الأبناء الذكور والإنـاث

تظهر فروق بين الذكور والإناث على مقياس الاتزان الانفعالي لصالح الإناث.

وتتفق نلك النتيجة مس نتائج العديد من الدراسـات والبحوث؛ التي توصلت إلى وجود فروق بين درجات الأبناء الذكور والإناث علي مقياس الاتزان الانفعالي لصالح الإناث

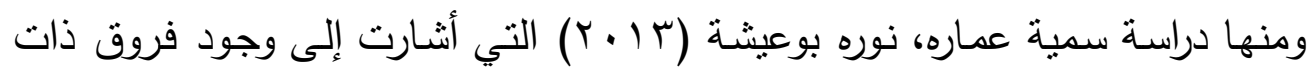
دلالة إحصائية بين الحوار الأسري والاتزان الانفعالي لصالح الإناتث، ودراسـة نانسي محمد (1/ ـ إ) التي توصلت إلى وجود فروق بين منوسطي درجات الإناث والذكور في جميع أبعاد مقياس النمو الانفعالي (الاتزان الانفعالي، الحساسية الانفعالية، الاستقله الانفعـالي) بمـا فـي ذلــك الدرجـة الكليـة للمقيـاس وذلــك لصـالح الإنـاث، ودراسـة جيفالد , Gevald (2010) والتي توصلت إلى أن الإناث أكثر تأثنراً بالغياب من الذكور . وقد اختلفت نلك النتيجة مـع نتائج بعض الدراسـات والبحوث؛ ومنها دراسـة فؤاد غالب (Y r r r التي أثنارت إلى عدم وجود فروق بين متوسطات الاتزان الانفعالي تبعاً لمتغير

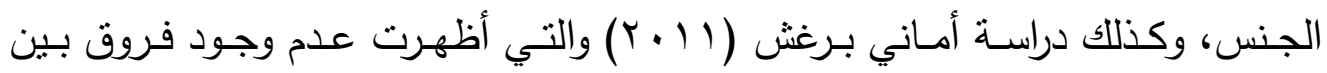
الذكور والإناث في الاتزان الانفعالي وذلك في مجموعة الطلاب الذين ينتمون إلى آباء يفكرون بطريقة سلبية. 
كما اختلفت تلك النتيجة مـع نتائج بعض الدراسـات والبحوث؛ ومنها دراسة رانيا عبد

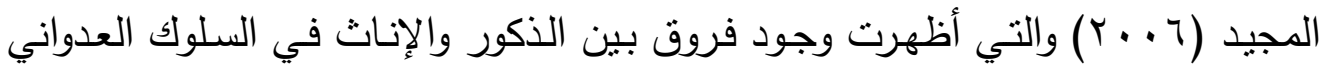

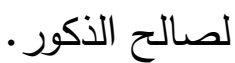

وقد يرجع وجود فروق بين الذكور والإناث في الاتزان الانفعالي للى الأبناء لصالح الإناث ذلك لأن طبيعة الأنثى تختلف عن طبيعة الذكر ، بالإضافة إلى اختلاف أساليب

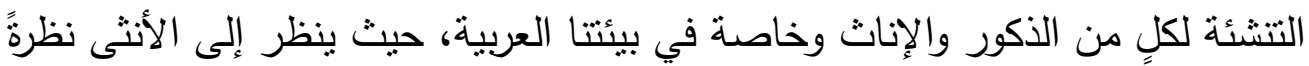
خاصة، وبأن لها دوراً يختلف عن الذكر، فهي أكثر حساسية للمواقف الانفعالية والعاطفية مما يجعلها تسعى إلى أن تكون أكثر استقراراً وضبطاً للنفس والانفعال، أو قد يرجع ذللك إلى طبيعة الواقع الاجتماعي الذي يعيشه كل من الذكور والإناث مختلف، وقد يعود ذلك إلى نوع التدعيم التي تتاله الإناث دون الذكور ، حيث إن هذا لئه التدعيم يسهم في اكتساب الاستقرار النفسي وضبط النفس والتحكم في الانفعالات. كما قد يرجع انخفاض الاتزان النفسي عند الذكور إلى أن الطفل (الذكر) يعمل على ئى

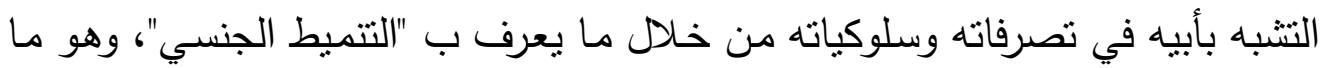

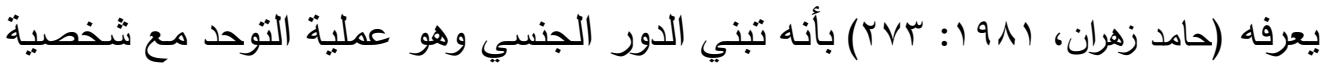
نفس الجنس واكتساب صفات الذكورة بالنسبة للبنين وصفات الأنوثة بالنسبة للبنات. وهو ما يؤدي بالطفل في كثير من الأحيان إلى السلوك العنيف والعدواني ان كان والده

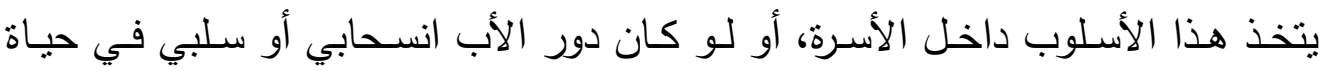

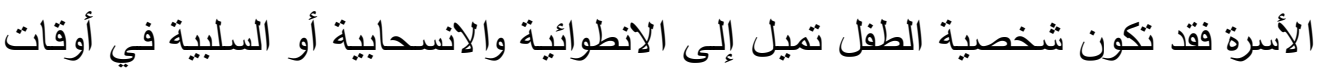
كثيرة، بعكس شخصية الإناث التي عندما يحدث لها التتميط الجنسي مع الأم فإنها تميل

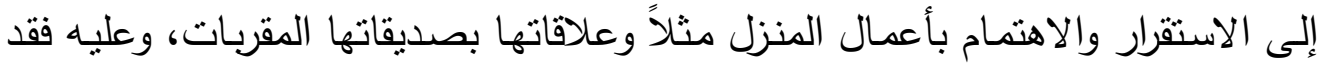

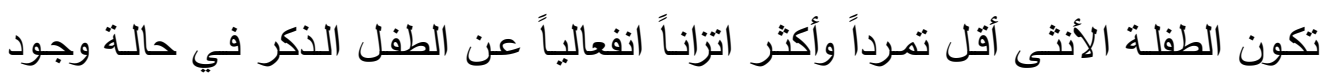
الطلاق العاطفي بين الوالدين. 


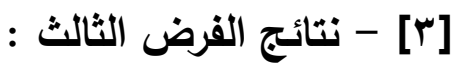

ينص الفرض على أنه: "لا توجد علاقـة دالـة إحصـائياً بين الطلاق العاطفي عنــ الزوجين والمستوى الاجتماعي الاقتصادي للأسرة".

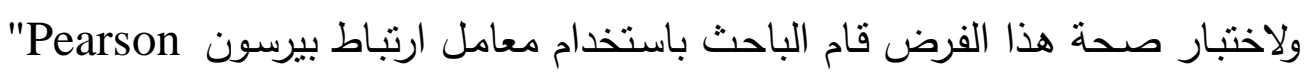

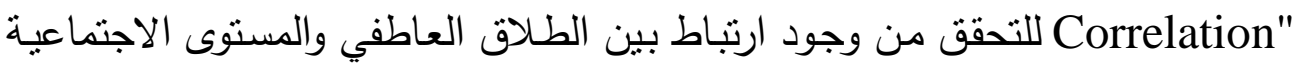

$$
\text { الاقتصادي للأسرة، ويتضح ذلك في الجدول (r): }
$$

جدول (ץ): معاملات الارتباط بين الطلاق العاطفي والمستوى الاجتماعية الاقتصادي للأسرة

\begin{tabular}{|c|c|c|c|c|}
\hline \multicolumn{5}{|c|}{ (ن } \\
\hline \multicolumn{4}{|c|}{ الاتزان الانفعالي (م= A } & \multirow{2}{*}{ 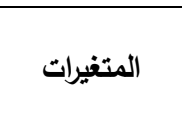 } \\
\hline الارتباط & الانحراف المعياري & المتوسط & العدد & \\
\hline . ITV & 11,10rT & \& & 74 & الطلاق العاطفي \\
\hline
\end{tabular}

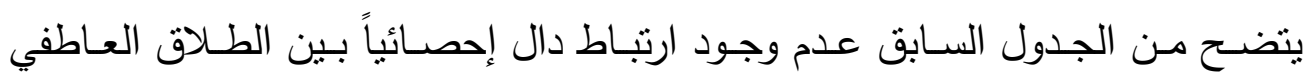

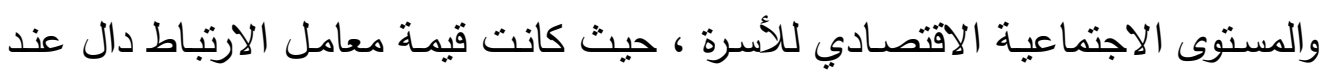
مستوى (1 (., ) (-).

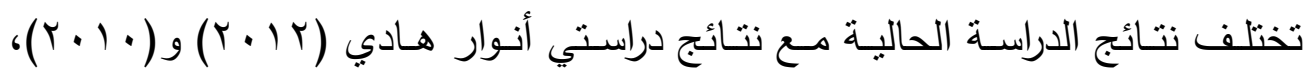

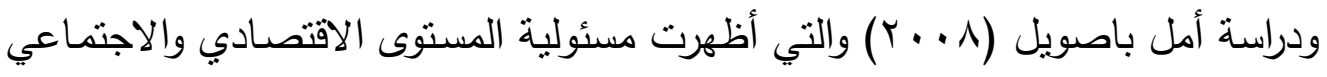

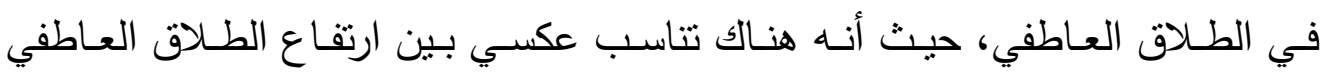
وانخفاض المستوى الاقتصادي والاجتماعي. وقد يرجع عدم وجود ارتباط بين الطلاق العاطفي والمستوى الاجتماعية الاقتصـادي للأسرة إلى أن نأثنر المستوى الاقتصادي والاجتماعي من الممكن أن يكون مؤثراً هاماً

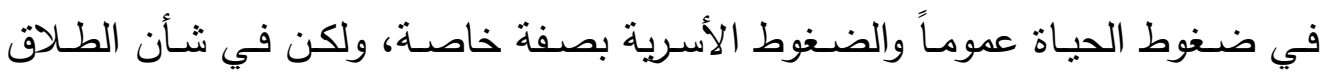
العاطفي فلقد وجد الباحث أثناء التطبيق ومن خلال تطبيق استمارة المستوى الاجتماعي

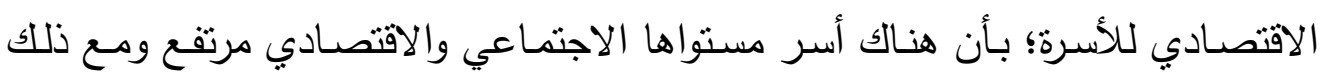

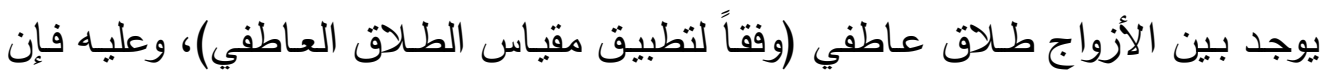
or 
الباحث يعزو هذه النتيجة إلى أن الطلاق العاطفي بين الزوجين ترجع إلى أسباب أخرى

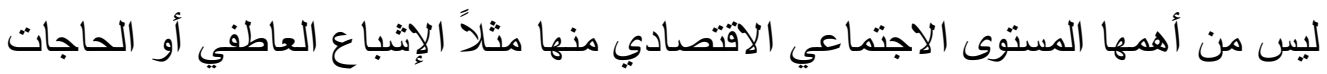

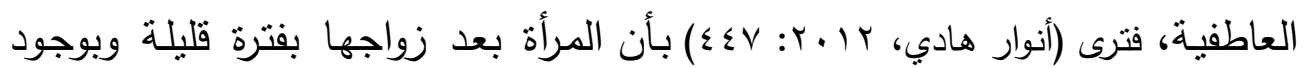

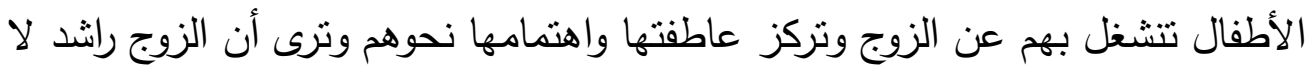
يحتاج إلى الحب والاهتمام بل هو معين للزوجة من اجل رعاية الصغار والاهتمام بهم لذا ينعرض الزوج إلى الإهمال من قبل الزوجة. وبالتالي فإن نقص الجانب العاطفي بين الزوجين يثير الغضب لدى الطرفين ويدفع إلى النفور والتفكك ويجعل التفاعل الزوجي مكلفاً نفسياً ويعرضه للانحراف أو التوقف لان لان في استمراره خسارة لا يقدر على تحملها الزوج وهذا يؤدي إلى التمرد النفسي.(كمال

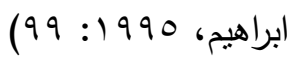
كما قد تكون هناك أسباب راجعة إلى طول مدة الزواج، حيث أن هناك بعض الأزواج

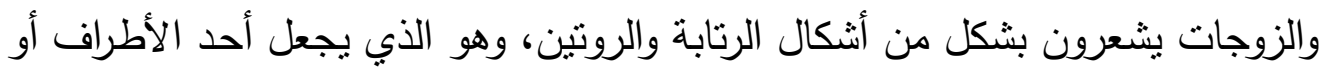

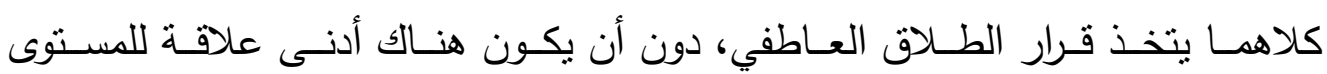
الاجتماعي والاقتصادي. فيرى (حسـان المـالح، 1990 1: 111 19191) أنـه عندما يشـر أحد الزوجين بالملل

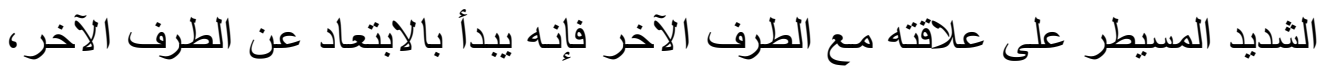

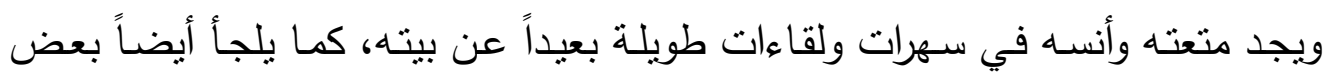

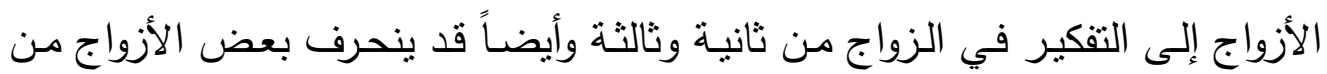
الجنسين نحو علاقات غير شرعية والتي تؤدي إلى تحطيم الزواج وتفسده .

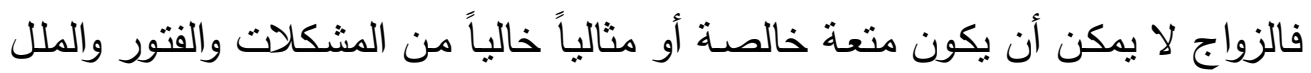
والاضطراب المؤقت ولا بد من الجهود المشتركة التي تسعى إلى تجديد العلاقة وإغنائها وبث الروح فيها فهناك عدد من الأساليب التي تساهم في ذللك. 
وعليـه يـرى الباحث بـأن المستوى الاجتمـاعي الاقتصـادي في أغلب الأحوال يكون معروف لدى الزوجين قبل الزواج وليس مفاجأة مالم تحدث انتكاسات ما وهذه الأندان الأحوال

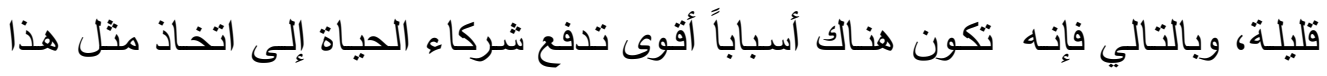
القرار ألا وهو الطلاق النفسي.

\section{التوصيات والبحوث المقترحة:}

-الاختيار السليم للزوج أو الزوجة عند بدء الحياة الزوجية، ودعوة الزوجين والمسئولين

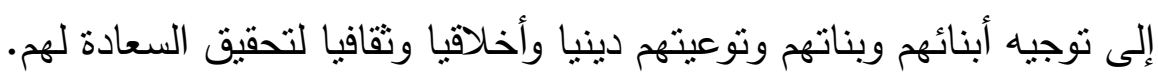
-تثقيف الآباء والتوفيق بينهم بشتى الوسائل للحفاظ على الأسرة من الطلاق العاطفي ونئي ونئي

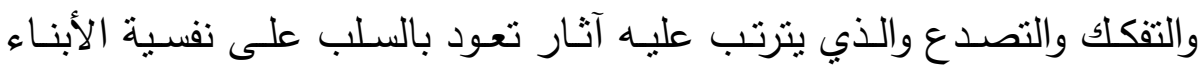
وضعف اتزانهم انفعاليا وشعورهم بالقلق وعدم الثقة في أنفسهم.

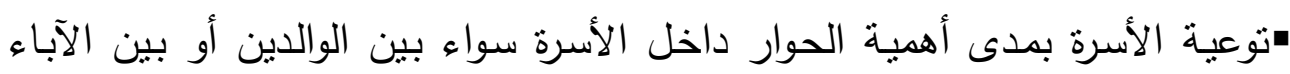

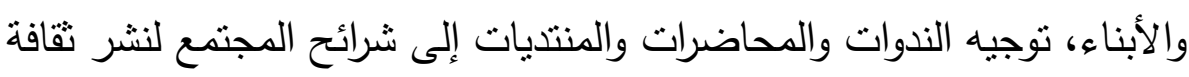

$$
\text { التوافق الأسري. }
$$

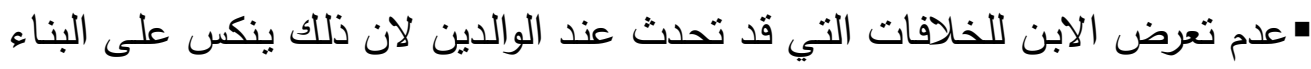

$$
\text { النفسي للابن، وبضعف التزانه الانفعالي. }
$$

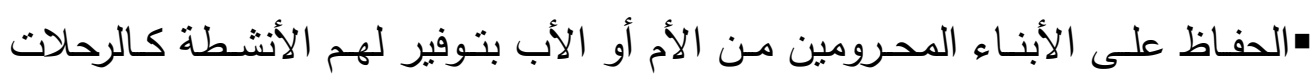

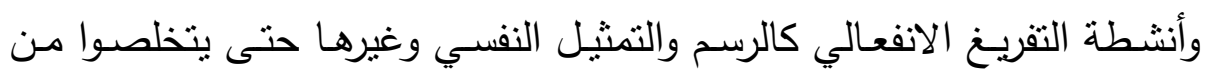
القلق والتوتر وتزبد اتزانهم الانفعالي وكذلك ثقتهم بأنفسهم. -توفير الحاجات المادية والنفسية من حب وعطف والثعور بالأمن النفسي لاىى الأبناء

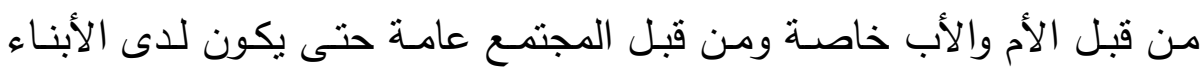

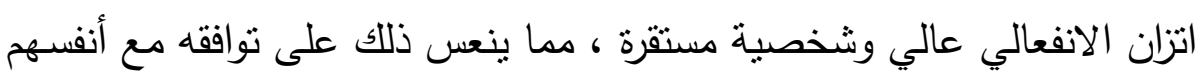
ومع المجتمع الذي يعيثون فيه. 
الطلاق العاطقى بين الزوجين وعلاقته بالإتزان الإنفعالى عند الأبناء د. نور الدين طه السنبارى .

\section{البحوث المستقبلية}

- الطلاق العاطفي وعلاقته بالمشكلات النفسية والاجتماعية لاى الأبناء. • الطلاق العاطفي وعلاقته بالسلوكيات السلبية لاى الأبناء المراهقين.

الاتزان الانفعالي والتوافق الزواجي لدي الآباء كمنبئ بالتلكؤ الأكاديمي لدى الأبناء.

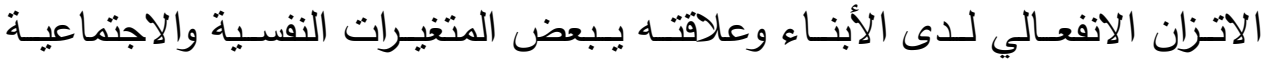

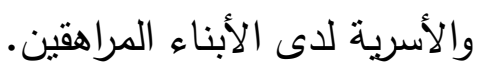




\section{قائمة المراجع}

\section{أولا: المراجع العربية:}

1- أحمد يحيي عبدالحميد: دراسات الأسرة والاتجاهات المعاصرة، القاهرة: جامعة قناة

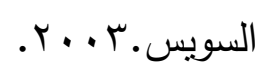

r- أسامه المزيني: القيم الدينية وعلاقتها بالاتزان الانفعالي ومستوياته لدى طلبة

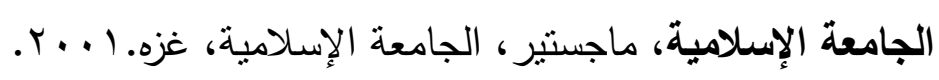

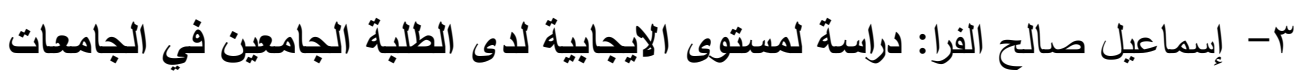

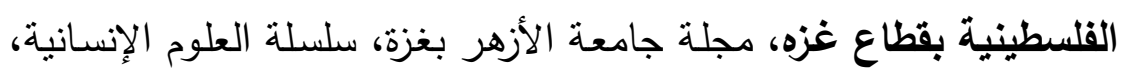

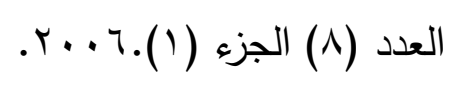

ع- أديب محمد الخالدي: سيكولوجية الفروق الفردية والتفوق العقلي، عمًان، الأردن:

دار وائل للنشر، 2003 .

0- أماني أحمد محمد برغش: التفكير الإيجـابي للآبـاء وعلاقتـهـ بالتحصيل الدراسـي

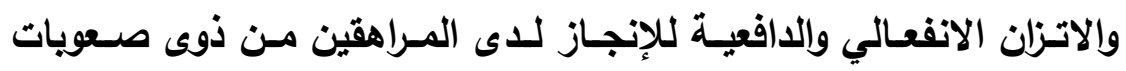

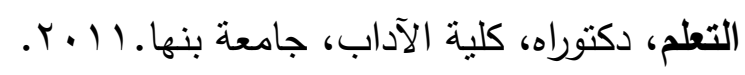

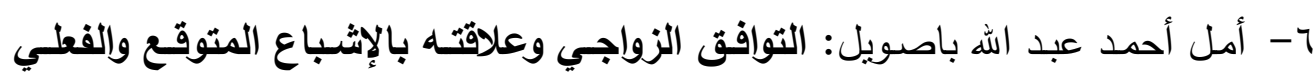

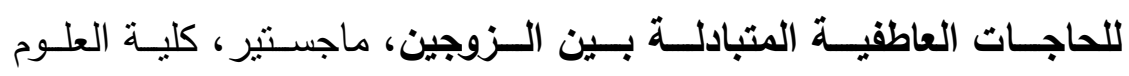

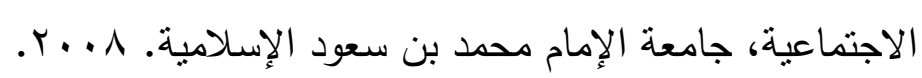

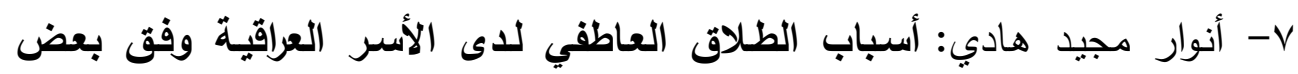

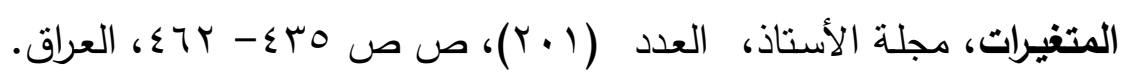

$$
\text { T. T }
$$

^- أنوار مجيد هادي: الطلاق العاطفي وعلاقته بفاعلية الذات لدى الأسر في مدينة

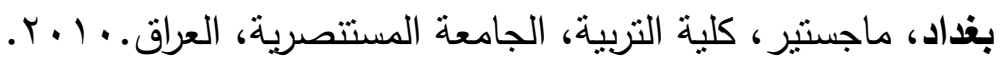
9- حامد عبد السلام زهران: الصحة النفسية والعلاج النفسي، القاهرة: عالم الكتب للنشر النش

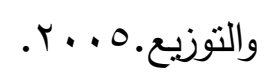

ov 


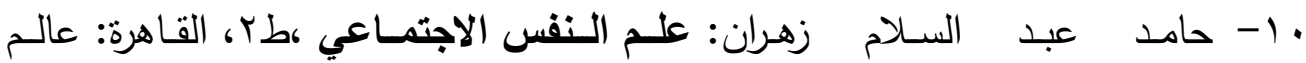

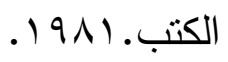

11 إ- حسان المالح: الخوف الاجتماعي، جدة: دار المنار . 1990 . r ا- حسن عبد المجيد رشوان: القانون والمجتمع، القاهرة: المكتبة الجامعية الحديثة. r...r

rا- حسن مصطفى عبد المعطي، هدى محمد قناوي:علم نفس النمو - المظاهر

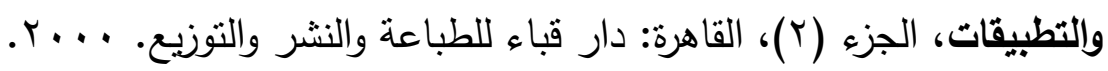

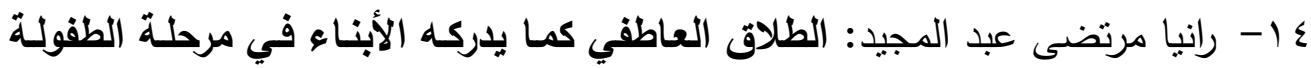

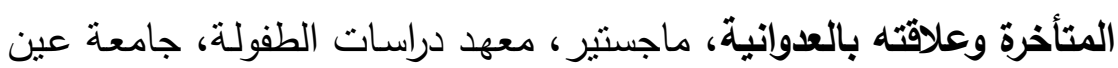

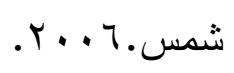

10- رشـا محمـود إبراهيم عبداللطيف: بعض المتغيـرات النفسـية المرتبطـة بـالخرس الزواجي وعلاقتها بالتوافق النفسي للأبناء، ماجستير، كلية التربية، جامعة إسة

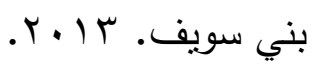

17

$$
\text { العربية السعودية: دار خوارزم العلمية للنشر والتوزيع. } 9 \text {. . . . }
$$

IV

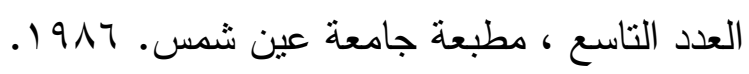

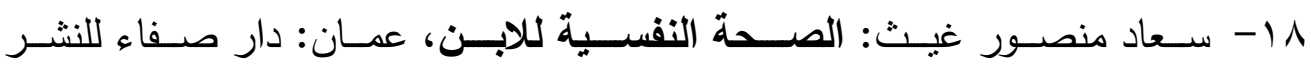

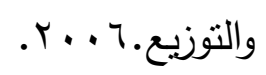

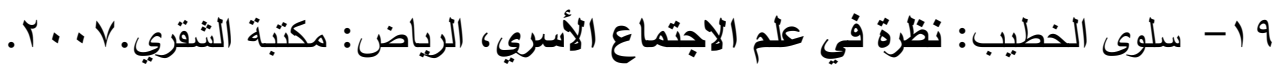

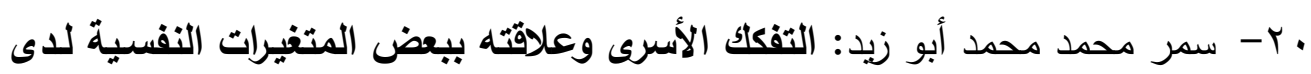
عينة من المراهقين بمدينة المنيا، ماجستير ، كلية التربية، جامعة المنيا.

$$
\text { .r. . } 9
$$

اب- سمية عماره ، نوره بوعيشة: الحوار الأسري وعلاقته بالاتزان الانفعالي للى

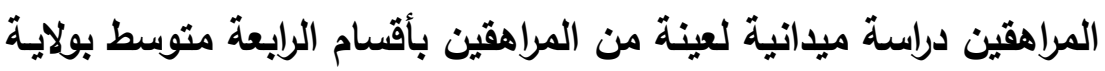




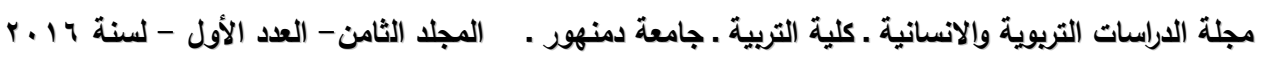

ورقلة ، الملتقي الوطني الثاني، جامعة قاصدي مرباح ورقلة ، كلية العلوم

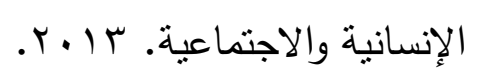

r

$$
\text { للكتاب. 1999. }
$$

بr- صالح الشعراوي: فعالية برنامج إرشادي عقلاني انفعالي سلوكي في تحسين

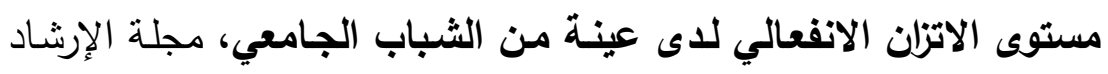

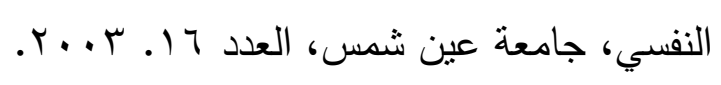

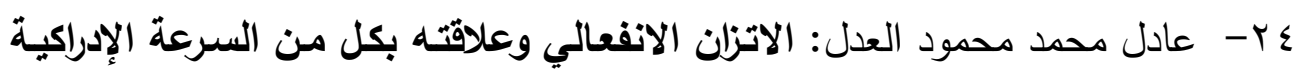

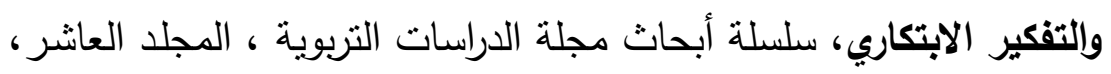

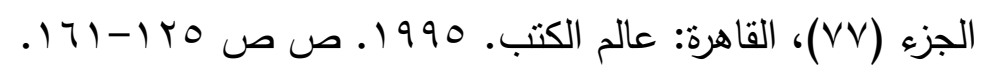

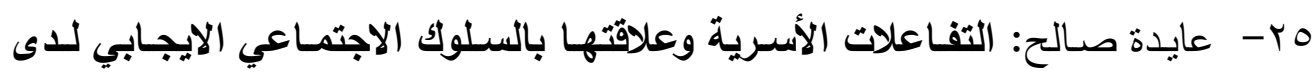

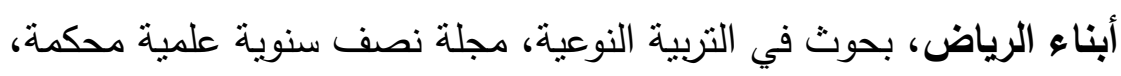

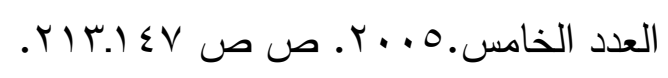

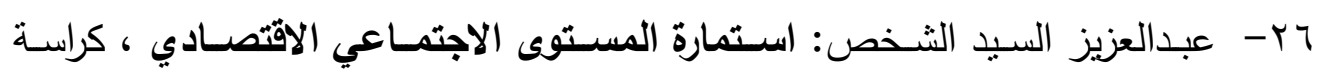

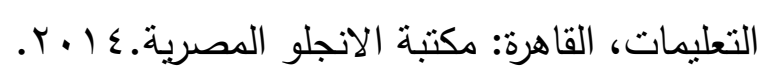

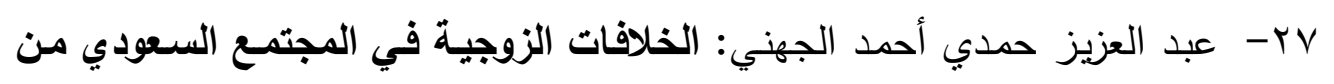

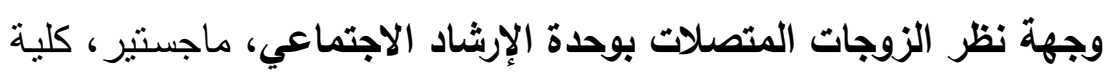

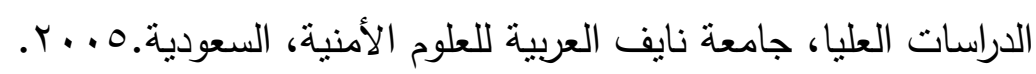

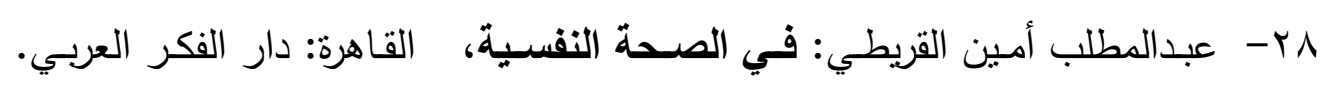
.1991

9ץ- علاء الدين احمد كفافي: الإرشـاد وإلعلاج النفسي الأسري : المنظور النسقي الاتصالي ، القاهرة: دار الفكر العربي. 1999.

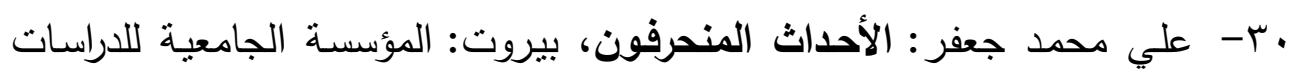

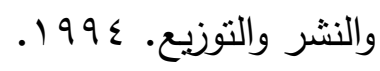


اب- فؤاد عبده مقبل غالب: نمو الأحكام الأخلاقية وعلاقتها بالاتزان الانفعالي وإلنضج

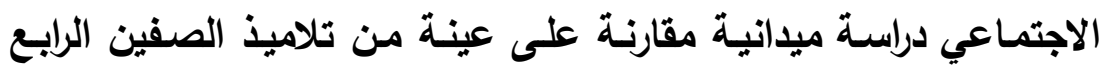

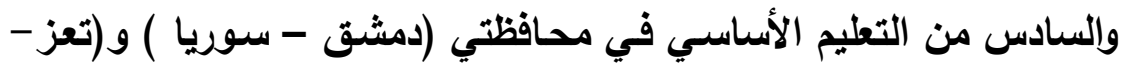

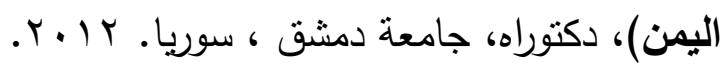

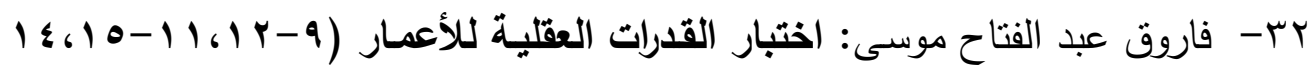
( V.$r \cdot r$

بr- فتحي عبد الواحد: التفكت الأسري وعلاقاته بالانحرافات السلوكية للأبناء (طلاب المرحلة الثانوية)، ماجستير ، جامعة حلوان، كلية التربية. 1999 1.

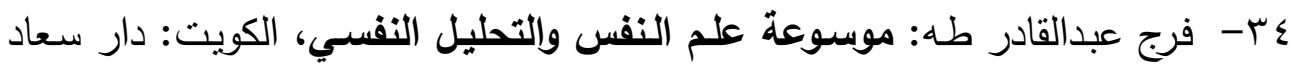

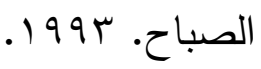

هr- كمال ابراهيم مرسي: العلاقة الزوجية والصحة النفسية في الإسلام علم النفس، الكويت : دار القلم للنشر والتوزيع • 1990.

צب- ماهر عمر : سيكولوجية العلاقات الاجتماعية، الإسكندرية: دار المعرفة الجامعية. .1911

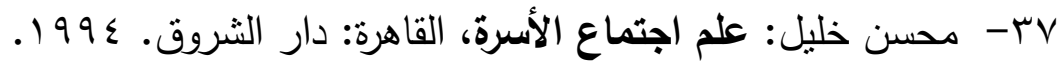

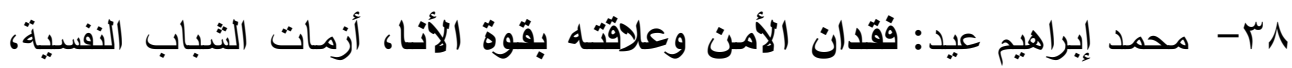

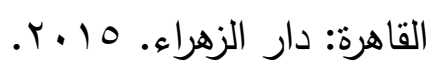

qب- محمد إبراهيم عيد: الاتزان الانفعالي وعلاقته بالاغتراب، القاهرة: الرسالة الدولية

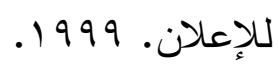

• ع- محد احمد النابلسي: الخلافات الزوجية ، مجلة النقافة النفسية المتخصصة، لبنان. .1991

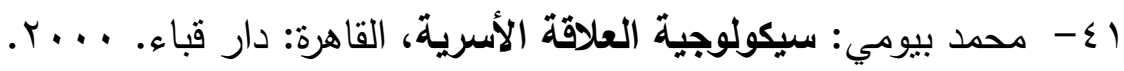

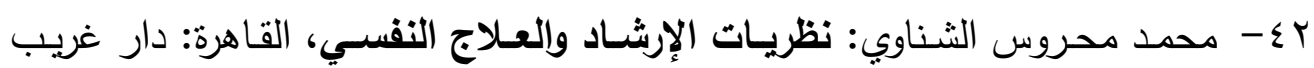

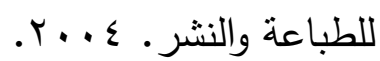

Doi: 10.12816/0044439 
rـ - محمود حسن: الأسرة ومشكلاتها، بيروت: دار النهضة العربية للطباعة والنشر. .1911

§ - مصطفى غالب: سيكولوجية الطقولية وإلمراهقة، بيروت: دار مكتبة الهله. .1991

؟ـ - مصطفى سويف: علم النفس الحديث - معالمـه ونمـاذج من دراساته، القاهرة:

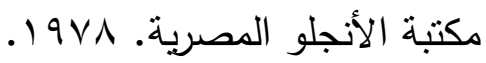

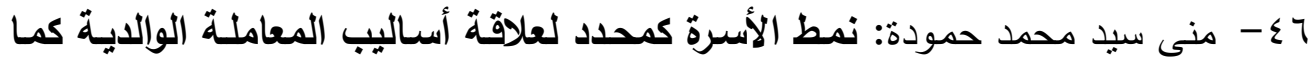

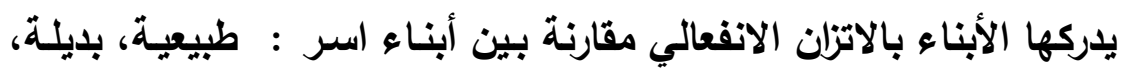

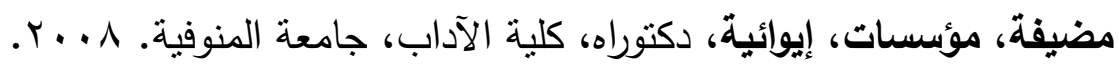

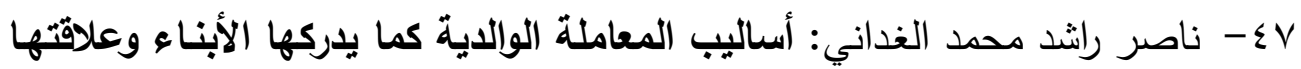

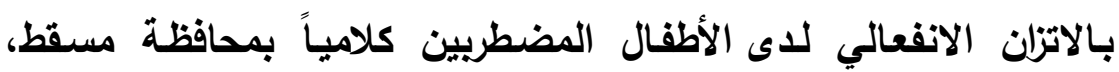

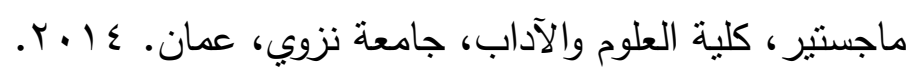

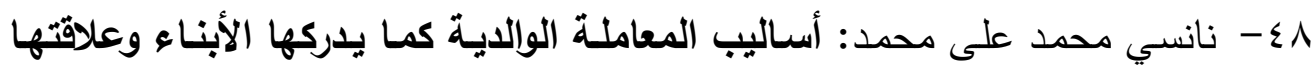

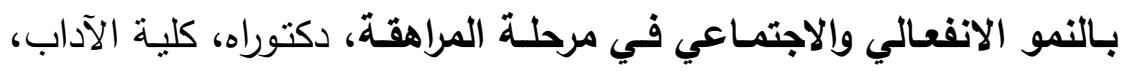

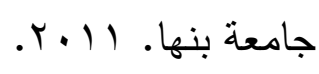
9؟- نويبات قدور : العلاقة الزوجية المتكدرة وآثارها على الصحة النفسية للزوجين

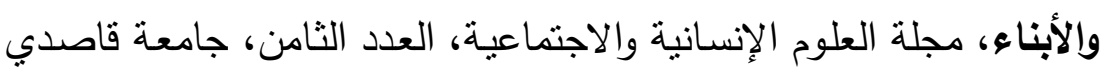

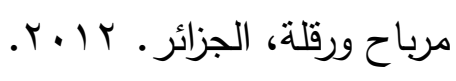
•- وبارت ميكافلين • ريتشارد غروس: علم النفس الاجتماعي، (ترجمة) ياسمين حداد،

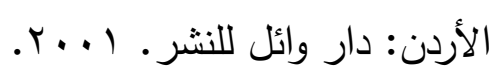

10- وفاء محمد عبد الجواد خليل: الرضا الزواجي من حيث علاقته بالبناء النفسي

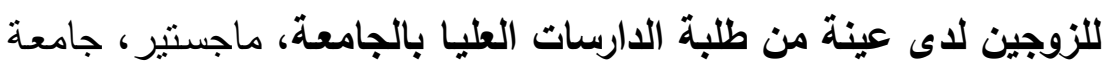
عين شمس. إن 199. 


\section{ثانياً: المراجع الأجنيةة:}

1- Beck A: Love is never enough, How couples can overcome misunderstandings, Resolve conflicts, and solve relationship problems, through cognitive therapy, perennial library, Harper \& Row publishers, New York.1989.

2- Colman , J.C.: Abnormal Psychology and Modern life, 3rd ed India , D.B.T. Sons and Co. 1970.

3- Ehrensaft, M. K., Cohen, P. Brown, J. Smailes, E. Chen, H. and Johnson, J., G.: Intergenerational transmission of partner violence: A 20Year prospective study, Journal of Consulting and Clinical Psychology. (71) 4. 2005.

4- Eysenck, H.J. and Arnold, w. and Milli, R. : Encyclopedia of psychology , vol 2 , Berne. 1972.

5- Gevald ,Nunn, D.: Perception of personal and familial adjustment by children from intact single parent reconstituted families, Journal from intact single parent reconstituted families. Journal social psychology, Vol. 20 (2).pp 166-175. 2010.

6- McNeal, C., Amato, P. R.: Parent's marital violence: Long-term consequences for children. Journal of Family Issues, 19,123-140. 2004.

7- Oates, R.K.: The spectrum of child abuse, Assessment, treatment, and prevention, New York: Brunner Mazel, Inc. 1996> 